\title{
Academic track mismatch and the temporal development of well-being and competences in German secondary education
}

\author{
Felix Bittmann ${ }^{1, *}$
}

\begin{abstract}
Formal education is one of the most influential predictors of professional success. As parents in Germany are aware of the importance of education, they often try to enable their children to enrol in the prestigious academic schooling track (Gymnasium). This explains why the transition recommendation made by the teacher after the fourth grade is sometimes ignored if the desired track was not recommended for a particular student. How the mismatch between the teacher's recommendation and the parents' choice of schooling for their child affects the child's development is not sufficiently known. It is very likely that such a mismatch can have consequences for the child's well-being, competences and overall academic success. Based on five consecutive panel waves of German National Educational Panel Study (NEPS) data (waves 1 to 5, collected between 2010 and 2016) $(n=2,790$ in wave 1$)$, our analyses demonstrate that social background and the probability of ignoring a teacher's recommendation are associated, and that highly educated parents are more likely to overrule the teacher's recommendation. Panel regression models show that pupils who pursued the academic track (Gymnasium) despite the absence of a teacher's recommendation were more likely to drop out of the academic schooling track, and were not able to catch up with their peers with respect to both objective and subjective academic competences over the entire observation window. However, the models also show that academic track mismatch did not seem to negatively influence the health and well-being of these pupils.
\end{abstract}

Keywords: German secondary education; well-being; competences; longitudinal analysis; mediation analysis; mismatch; school tracking; teacher's recommendation

\footnotetext{
${ }^{1}$ Leibniz Institute for Educational Trajectories (LIfBi), Department: Educational Decisions and Processes, Migration, Returns to Education, Bamberg, Germany

*Correspondence to: Felix Bittmann, felix.bittmann@lifbi.de
} 


\section{Introduction}

Education undoubtedly plays a fundamental role in social and economic development, and the professional success and income of individuals depend to a large extent on the educational qualifications they have obtained (Triventi 2013). This relationship is also known to parents, who usually try to support and encourage their children to perform well academically. Parental involvement in school choice is particularly important in the German educational system, in which the age of first selection is early, and the children undergoing this process are hardly fully aware of the implications of choosing a secondary school (Jonkmann et al. 2010). However, in addition to the desires of the parents, a teacher's recommendation after the completion of the fourth grade of primary school also plays a vital role in school choice. Depending on the federal state, class teachers make either a binding or a non-binding school recommendation regarding the type of secondary school the student should attend. This recommendation reflects the teacher's impression of which school and learning environment is suitable for the student based on the child's previous performance and grades (Füssel et al. 2010; Lohmann and Groh-Samberg 2010). In the literature, this recommendation is considered to be extremely influential, as it can have a significant impact on the further course of the child's education (Billmann-Mahecha and Tiedemann 2006). If the teacher does not recommend enrolment in the academic track, the parents may disagree with this judgement, as they want their child to enrol in the most prestigious track, which leads directly to eligibility for higher education. If there is a mismatch between the teacher's recommendation and the type of school the parents choose for their child, the teacher's recommendation can often be ignored, as the binding character of this recommendation has been abolished in most federal states. ${ }^{1}$ Thus, German parents have greater autonomy in the choice of schooling for their child today than they had in the past, but they are also assuming a greater degree of responsibility. The following question therefore arises: When the parents decide against accepting the teacher's recommendation regarding the type of school their child should attend, how is the child's future educational achievement and development affected?

While previous studies have investigated the association between track mismatch and various outcomes in secondary education, these analyses were not complete. For example, it is known that grades are associated with both health status (Rathmann et al. 2017) and well-being (Herzberg 2013). However, since these studies were based on cross-sectional analyses, they could not determine the direction of causality. All in all, it is clear that there is little existing empirical research on the relationship between educational track mismatch and its further consequences.

\footnotetext{
1 Note that in this article, only the states where the teacher's recommendation for secondary school track choice is not binding are included in the analysis. Since there are no further entrance tests at the Gymnasium level, the children can then transition to the academic track even if their academic performance was poor in primary school.
} 
Nonetheless, analyses of official data have shown that children who lack a teacher's recommendation to enrol in the academic track are less likely to stay on the academic track (retention rate). For example, it has been estimated that just under 70.2\% of all pupils with an intermediate secondary track (Realschule) recommendation and $55.0 \%$ with a lower secondary track (Hauptschule) recommendation are still attending the Gymnasium by the seventh grade (Tiedemann and Billmann-Mahecha 2010). However, as these figures are reported two years after the start of secondary education, the long-term trajectories of these pupils are not known. Since the final school-leaving certificate (Abitur) is obtained after students have spent eight or nine years in secondary education, extending the window of observation would clearly provide more detailed insights into their trajectories. A second major limitation of these studies is that they examined a relatively small number of outcomes. These constraints were often due to the limited scope of the surveys the studies were based on, since carrying out longer and more detailed questionnaires would have increased survey costs. Moreover, even the surveys that collected more extensive data usually surveyed the participants only irregularly. However, the comprehensive NEPS dataset includes a much wider range of relevant outcome variables, many of which are surveyed every year. Thus, the NEPS provides a rich dataset for longitudinal analyses. In summary, the objectives of the present study are to extend the current state of research, and to perform genuine longitudinal analyses of the effects of academic track mismatch. Whereas in the past, only cross-sectional analyses or analyses with two points in time were available, we can now use newly available data to trace the complete school progression of children from grades five to nine. In addition, we can now analyse various other aspects of students' lives that have so far been insufficiently investigated, but can be regarded as valuable indicators of their development, such as well-being and health status (Ravens-Sieberer et al. 2000).

Exploiting longitudinal data drawn from the German National Education Panel Study (NEPS), this paper aims to answer the following research questions:

- How is the decision by a child's parents to overrule the teacher's recommendation, and to enrol the child in the academic track even when another track has been recommended, related to the social origin of the child?

- How do the retention rates, competences (math and German competences tested by the NEPS) and grades of children enrolled in the academic track without a teacher's recommendation develop compared to those of children with a teacher's recommendation?

- How do children who are enrolled in the academic track without a teacher's recommendation fare in terms of other aspects of life - including well-being, enjoyment of reading and general health - compared to children with a teacher's recommendation?

- Can differences in the academic achievement and well-being levels of the two groups of children be explained by the children without a teacher's recommendation having insufficient academic competences? 
The rest of the article is structured as follows. After giving a brief overview of the German educational system and the theoretical background of the research, testable hypotheses are formulated. In the empirical analyses, which examine the experiences of pupils who were recently enrolled in the academic track in secondary education in federal states where the binding character of the teacher's recommendation has been abolished, longitudinal panel regressions based on data from the German National Educational Panel Study (NEPS) are performed to investigate these questions, and to test for mediation effects. The findings are then summarised and discussed. The main contribution of the following analyses is to generate a comprehensive picture of the overall development of pupils in secondary education by extending the window of observation using five waves of panel data, while taking into account a large set of relevant outcomes. The inclusion in the analyses of a large set of relevant control variables further strengthens the robustness of the results, and reduces the probability of spurious findings.

\section{Background and theoretical framework}

This section describes the German educational system with a focus on school and track differentiation. It also discusses the conceptual framework underlying our research hypotheses.

\subsection{The German educational system}

Here, we provide an overview of the German educational system (primary and secondary education). In grades 1 to 4 (which span an average age range of 6-7 to 10-11 years), pupils attend primary school. Based on their performance in primary school, pupils are then sorted into one of the four qualitatively different tracks (Eckhardt 2017). For each pupil, the grade four teacher makes a recommendation, which is either binding or non-binding depending on the federal state, regarding which secondary education track the pupil should be enrolled in based on his or her general academic achievement and development potential. The five-year lower secondary school track (Hauptschule), which prepares pupils for low-skilled service or manual work, is the least demanding. The six-year intermediate track (Realschule) provides pupils with vocational training in skilled white-collar or service occupations. The nine-year upper secondary school track (Gymnasium) prepares pupils to obtain the qualifications needed to enter university (Abitur), and is regarded as the most prestigious. Furthermore, most federal states have introduced comprehensive schools (Gesamtschulen) in addition to the tracked tripartite school system. These comprehensive schools can be seen as another approach to making the secondary school system more permeable. While comprehensive schools usually offer all three of the school-leaving certificates issued by the traditional tripartite school system, students can continue from one level to the next level given adequate 
performance. Thus, a comprehensive school can combine several tracks within one institution, and enable students to move between the tracks. In general, the hierarchy of the schools' performance requirements is as follows, from lowest to highest: Hauptschule, Realschule, Gesamtschule, Gymnasium.

After the final year of elementary school (grade four), the class teacher gives a track recommendation for each pupil that is based on the teacher's overall impression of the pupil's abilities and competences, including the child's social and soft skills and potential for further development.

\subsection{Teacher recommendations, mismatch and social origin}

As was explained above, even when a child is a low performer, the parents may be motivated to overrule the teacher's recommendation and to enrol the child in the academic track; i.e., in the school track that is associated with the best outcomes and the highest wage premiums. It has always been possible for parents to choose to enrol their child in a less demanding track (for example, the teacher recommends the academic track, but the parents select the intermediate track instead). Recently, parents have been given the option to overrule the teacher's decision and select a more demanding track for their child (for example, the teacher recommends the intermediate track, but the parents choose the academic track instead). In our analyses, we refer to a situation in which a child was enrolled in the academic track (Gymnasium) in grade five, and had received a teacher's recommendation to do so, as a match. Conversely, we refer to a situation in which a child was enrolled in the academic track, but had received a teacher's recommendation to enrol in a less demanding track in grade four (i.e., the parents overruled the recommendation), as a mismatch. Children who were not enrolled in the academic track in grade five are not of interest for our study, and are not considered in the theoretical expectations or analyses.

In order to clarify which social classes tend to accept a mismatch condition, the concept of primary and secondary effects of Boudon (1974) can be applied. Boudon argued that educational inequality is caused primarily by two factors. First, he noted, socially disadvantaged children tend to have lower academic performance than other children, including lower grades and standardised achievement test results (primary effects). Boudon attributed this lower performance to socially disadvantaged families being less able to invest in their children's education by, for example, providing them with individual early support or tutoring. He also identified secondary effects related to educational decisions. Boudon argued that compared to their more advantaged counterparts, children from disadvantaged backgrounds are less likely to achieve high educational qualifications even when their academic performance levels are the same, and are therefore more likely to choose the lower schooling tracks. He explained this tendency by observing that socially disadvantaged families often regard attending the Gymnasium as a comparatively long and costly educational route with a lower probability of success. This view has been 
further supported by the concept of relative risk aversion, which posits that children must primarily reproduce the social status of their parents (Breen and Goldthorpe 1997; Esser 1999). Thus, children from the higher social strata are expected to at least secure eligibility to enrol in higher education, as this is seen as the only way for the parents to achieve their desired level of status; whereas children from disadvantaged families are not expected to earn more than a lower diploma (Stocké 2007). Thus, the motivation to attend the Gymnasium is often not educational in nature (Schulze et al. 2009; Sewell and Shah 1968). If this is the case, which children belong to the group of pupils who have to ignore the teacher's recommendation to enrol in the Gymnasium, rather than in a lower track? Since the recommendation should be based primarily on the child's academic performance, and not on his or her social class affiliation, these individuals are likely to be low-performing students who have not achieved the required grade point average. Based on the primary effects argument, this group should include many socially disadvantaged children, as well a few children who are more socially advantaged. Nevertheless, based on the secondary effects argument, it may be assumed that among the children in this group, the more socially advantaged children (and their parents) in particular are motivated to ignore the teacher's recommendation that the child enrol in a lower secondary track, and thus proceed to enrol in the Gymnasium. Furthermore, it is known that compared to their more socially advantaged counterparts, socially disadvantaged families tend to be less informed about the education system, and to rely more on teacher recommendations (Harazd and van Ophuysen 2008). Based on this argumentation, the following research hypothesis can be formulated: parents who overrule the teacher's recommendation that their child enrol in a less demanding track by sending their child to the Gymnasium tend to belong to the higher social classes (Hypothesis 1).

This expectation is supported by previous research. For example, it is known that in Germany, social origin influences the probability of transitioning to the Gymnasium, even when controlling for the actual performance (Ditton and Krüsken 2006; Stubbe and Bos 2008); and that children from socially disadvantaged families are less likely to receive a recommendation to attend the Gymnasium, even if their performance is equal to that of their more socially advantaged counterparts (Dumont et al. 2014; Maaz et al. 2008). These effects are also stronger in federal states without a binding teacher recommendation (Gresch et al. 2010), which means that in these states, the parents often overrule the teacher's recommendation. Overall, the secondary effects appear to be responsible for almost $60 \%$ of the educational inequality that arises in the transition to upper secondary school (Neugebauer 2010). Other studies have also concluded that parents from the higher social strata are especially like to ignore undesirable recommendations, whereas parents from the lower social strata are more likely to accept them (Ditton et al. 2005; Harazd 2008). This discrepancy can also be attributed to evidence indicating that social position and educational aspirations are positively correlated. Therefore, it may be assumed that socially disadvantaged families are less likely to want their children to attend the Gymnasium in the first place (Haunberger and Teubner 2008). In order to go 
beyond the results of these previous studies, the following analyses will extend the window of observation by several years, as longer running panel data have recently become available. In contrast to either cross-sectional studies or panel analyses with only two waves, including a large number of survey waves allows us to trace the development of children over a longer period of time, which has several advantages. First, the problem of outliers and errors is reduced since the total number of data points is larger. Second, it makes it easier to recognise general trends over time (like up- or downward trends), and thus to draw more robust inferences. For example, it is possible that pupils with a mismatch condition have abilities that are comparable to those of pupils without a mismatch condition at the beginning of secondary education, but that the gap in performance between these two groups widens as the pupils progress. These diverging trends can be studied in detail only when several time points are included. Thus, our study has an advantage over previous studies, which often drew conclusions from a smaller number of points in time. Clearly, the more data that are available, the more precisely we can investigate the general development of pupils.

\subsection{Well-being and academic performance}

In light of the considerations outlined above, the following question arises: How does a mismatch condition - that is, enrolling in the academic schooling track without a teacher's recommendation - affect a child's subsequent educational achievement and success? Does a child with such a mismatch have lower chances of successfully completing the academic track? How do indicators of a child's success in life, such as his or her well-being and academic performance, as well as other relevant factors, such as the enjoyment of reading, develop over time? First, there is evidence that from the outset, children with a mismatch have lower academic performance than their classmates in the academic track (Klicpera et al. 1993; Stern 2008). This seems logical, as previous differences in the academic performance of these two groups is the main reason for the mismatch. It can, therefore, be assumed that these children do not meet the performance standards of the Gymnasium, or at least have below-average performance. If these children are unable to overcome their academic shortcomings, they may have to repeat the grade or even transfer to another type of school. Ultimately, these pupils are generally found at the lower end of the intra-class performance distribution, which is communicated to them by, among other things, the grades they achieve (Pfost et al. 2018). These observations can be further explained by the big-fish-little-pond effect. It is well known that for students, their own class is the most important reference group, and the comparison with their classmates has a particularly large impact on their academic self-concepts (Möller and Trautwein 2015; Zeinz and Köller 2006). Pupils whose performance is poor relative to that of the reference group are, therefore, negatively influenced (Köller 2004). Based on these findings, we can expect to observe that students who attend the Gymnasium without a teacher's recommendation will, on average, 
have worse academic outcomes than their classmates (Hypothesis 2). This working hypothesis is supported by previous findings, and serves as a starting point for the following analyses (Klicpera et al. 1993; Stern 2008). Furthermore, it can be assumed that the negative effects of a mismatch are ultimately caused by inadequate school performance, since performance is regularly tested and communicated by grades (Hypothesis 3). A pupil with unsatisfactory results will find herself at the lower end of the performance distribution, and will also face the problem of not being able to advance to the next school year, which is an objective measurement of failure that can cause the pupil to experience stress, to develop negative attitudes towards schooling, or to develop low self-esteem.

\section{Empirical analyses}

\subsection{Data and sample}

The empirical analyses we use to test our hypotheses are based on data from the German National Education Panel Study (NEPS) (Blossfeld et al. 2011). ${ }^{2}$ The NEPS has been collecting longitudinal individual data (panel data) in a multicohort sequence design since 2008. For the present study, we use the starting cohort 3 (data version 8-0-0), which includes secondary school students who have been surveyed annually since the fifth grade; i.e., the first grade of secondary school. The target population for the starting cohort 3 consists of all children in Germany who were enrolled in fifth grade in Germany in the 2010/2011 school year. At the time the analyses were performed, information was available for grades five to nine; i.e., a total of five survey waves were conducted between 2010 and 2016. These prospectively collected individual data cover a range of relevant dimensions, such as competence development, grades, and health; but also socio-demographic variables, such as social origin, as measured by the educational degrees of the parents and their ISEI classification. Thus, the NEPS data are well-suited for the purposes of the present study. The teachers' recommendations in the fourth grade are also available.

The total sample consists of 5,753 students enrolled in the fifth grade of secondary school. This sample is additionally restricted. First, pupils from federal states that had a binding teacher recommendation at the time of the first selection (the transition to secondary education) were removed from the sample, because in such cases, the teacher's decision could not be ignored, and a mismatch was, therefore,

\footnotetext{
2 This paper uses data from the National Educational Panel Study (NEPS): Starting Cohort Grade 5, https://doi.org/10.5157/NEPS:SC3:8.0.0. From 2008 to 2013, NEPS data were collected as part of the Framework Program for the Promotion of Empirical Educational Research funded by the German Federal Ministry of Education and Research (BMBF). As of 2014, the NEPS was carried out by the Leibniz Institute for Educational Trajectories (LIfBi) at the University of Bamberg in cooperation with a nationwide network.
} 
not possible. These federal states were Bavaria, Baden-Württemberg, Bremen, Saxony and Thuringia (i.e., five out of the 16 federal states, which underlines the general trend in Germany towards abolishing the binding character of the teacher's recommendation). This leaves 3,345 pupils. In addition, the states of Berlin and Brandenburg are excluded because in these states, the first selection takes place in the sixth grade. Children who attended a special needs school (Förderschule) are also excluded, since it can be assumed that our theoretical concepts do not fully apply to them. This leaves a sample of 2,790 children for analyses in wave 1 (raw sample).

\subsection{Operationalisation}

As explained above, theoretically, students at both the academic track schools (Gymnasium) and the comprehensive schools (Gesamtschulen) can earn the qualifications needed to enter higher education (Abitur). In the data, it is not always possible to distinguish which types of comprehensive schools provide this option, and which do not. Therefore, all analyses were carried out twice. In the first definition, only the academic track schools provide this option; while in the second version, both academic track and comprehensive schools are analysed together, and are considered to be equivalent. By using this approach, very precise effects can be estimated. Note that the second form of operationalisation always contains a larger number of cases. The variable of interest, mismatch, is binary, and is operationalised as follows: if a child in grade five attends either the Gymnasium (or a comprehensive school, depending on the operationalisation) despite not having a teacher's recommendation to enrol in this track, this is classified as a mismatch (coded 1); whereas if a child attends the Gymnasium after having received the corresponding recommendation, there is no mismatch (coded 0 ).

The social background is operationalised in accordance with Boudon's theory of the two effects via the highest school-leaving qualifications the parents achieved, as doing so enables us to directly measure whether a particular school type can reproduce the parents' school-leaving qualifications. While there are other options available for operationalising social background (e.g., Erikson-GoldthorpePortocarero class scheme (EGP) or International Socio-Economic Index of Occupational Status (ISEI)), in the context of the German system - in which the educational degrees students earn are decisive for their subsequent life course, since these qualifications have a gatekeeping function that allow students to enrol in specific educational tracks - using these qualifications seems most appropriate, as each degree has a clear and inherent meaning. If information on the schoolleaving qualifications achieved by both parents is available, the higher of the two degrees is used (principle of dominance). To create categories of approximately equal size, they are operationalised as follows: no degree, lower (Hauptschulabschluss) or intermediate degree (Mittlere Reife) (1), any higher education eligibility (Fachabitur or Abitur), (2) and any higher education degree (3). For the sake of 
simplicity, social background and parental educational qualifications are sometimes considered equivalent in the further analyses, even if the two concepts are not identical. Parental social status is measured by the highest ISEI (International Socio-Economic Index of Occupational Status) level, which includes additional information on the occupational status of the parents. These variables are included as control variables in the longitudinal models.

The objective academic competence or performance of students is measured by standardised competence tests, which the NEPS conducts in grades five, seven and nine. The tests cover competences in mathematics, reading skills and orthography. Reading competence is tested via 32 items in a partial credit model (Pohl et al. 2012). Mathematics competence is calculated from 24 items, which include aspects such as counting, spatial thinking, form and probability (Duchhardt and Gerdes 2012). As these different areas of competence are highly correlated, for the sake of simplicity, a single performance score is generated, which has a high Cronbach's Alpha (an Alpha in each wave greater than 0.86). Since the competences are only measured three times over the five ways, they are imputed in the two missing waves by averaging the two adjacent measurement points, if both were available. Further information on the competence measures of the NEPS can be found in the data manual (Fuß et al. 2019). As a second performance indicator, we use the school grades achieved in the subjects of mathematics and German from the annual reports. These grades are, in turn, combined into a single score by means of simple averaging. The German grade system ranges from one (best grade) to six (worst grade), so lower values indicate a higher performance. As both grades and objective competences were z-standardised by wave, the results can be interpreted in standard deviations. This approach also removes any growth and time effects from the data, which is beneficial for the following analyses.

Well-being is measured by general life satisfaction, and is generated from six Likert-scaled individual items (Alpha always greater than 0.76), which have already been tested in previous studies (TNS Infratest Sozialforschung 2009). ${ }^{3}$ This variable will be referred to as general well-being, and is available in all five waves (von Collani and Herzberg 2003). The subjectively perceived health status of each pupil is measured on a scale of zero ("very poor") to four ("very good"), and is taken from the pupil questionnaires. As another indicator of general well-being and health, each pupil's self-reported days of absence from school in the past four weeks are selected. Values above the $99^{\text {th }}$ percentile (corresponding to more than 15 days of absence) have been removed from this item to avoid distortions due to outliers. We assume that pupils with health problems will have a higher number of days absent from school. The enjoyment of reading is measured using six different Likert-scaled items (Möller and Bonerad 2007), and indicates how much a child

\footnotetext{
3 The items are as follows: "How satisfied are you currently, all in all, with your *?" The asterisk indicates the following areas of life: "life" (1), "standard of living" (2), "health" (3), "family life" (4), "friends and acquaintances" (5), "situation at school" (6).
} 
enjoys reading (Alpha always greater than 0.85). This variable is selected to measure the child's subjective interest in reading. The age of the children is measured in years in wave 1 . The absolute age of the child is used to capture his or her overall cognitive development, which might be confounding if the parents sent the child to school earlier or later than the other children.

\subsection{Strategy of analysis}

It is important to note that in the analyses, a hierarchical data structure exists, as up to five data points are available for one person. In the longitudinal analyses, this clustering must be taken into account in order to estimate standard errors correctly. In addition, missing information is imputed to the extent possible in order to increase the effective number of cases. Multiple imputation with chained equations (MICE) is utilised. In each case, 40 imputations are generated after a burn-in of 60 iterations (Allison 2001). Common diagnostic criteria for imputations, such as convergence, were examined and approved. Some statistics about the total number of imputed values and convergence are presented in the appendix (Table A.1 and Figures A.1 and A.2). It should be noted that analyses that do not make use of any imputation procedures report basically the same results and conclusions. Thus, we are confident that the imputation does not disturb or bias the analyses in any way.

First, purely descriptive statistics are reported for all of the relevant variables in order to get a general impression of the distribution of the variables. Then, a first cross-sectional model is used to test how social origin and mismatch are related. The sample includes all children in grade five who did not receive an academic track recommendation $(n=1008)$, and may, therefore, have ignored it. This enables us to test which of these children nevertheless enrolled in the academic track. The dependent variable is binary coded (academic track/comprehensive school $=1$, other school type $=0$ ). The key explanatory variable is social origin, measured by the highest parental educational certificate with three levels.

In all of the subsequent analyses, only those children who actually enrolled in the Gymnasium in the fifth grade are included ( $n=862$ in schooling year five). This enables us to test what effects a mismatch had on a child's outcomes. Multilevel growth curve models are utilised to take the data structure into account. The dependent variables are the probability of remaining in the academic track (retention rate), competences and grades, well-being, self-assessed health, days absent from school in the last four weeks, and the enjoyment of reading. Depending on the scaling of the dependent variable, different statistical models are used, which are described in more detail below. All graphs contain $95 \%$ confidence bars to test for significant differences between groups. Unlike most other growth curve models, we use a different parametrisation, since the number of waves was low, and all of the pupils were interviewed at virtually the same point in time. This approach allows for a very flexible estimation of effects, and does not require us to make assumptions about the functional form of the temporal developments of outcomes. 
In the final mediation analysis, we examine whether the group differences in outcomes between the pupils with and without a mismatch can be explained by their competences or grades. Longitudinal panel regressions with random effects are utilised. By employing a nested model design, the strength of the mediation can be assessed.

Since spurious correlations are always possible in studies using observational data, these should be mitigated or eliminated by including relevant control variables. The following variables were selected as potential confounders: the gender of the child, the child's migration background (both parents born in Germany/one parent born abroad/both parents born abroad), ${ }^{4}$ the highest parental educational level, the highest parental ISEI level, the age of the child, whether the parents were living together (including whether the parents were divorced, widowed or single) and the federal state where the school was located. It should be noted that due to the data protection regulations for the NEPS, we are not allowed to publish regression coefficients that were computed for the federal states; thus, these coefficients are not included in the output tables.

All calculations are computed in Stata 16.1, using, among other programs, the user program mimrgns, which is needed to calculate the average margin effects for the imputations (Klein 2014).

\section{Findings}

First, the descriptive statistics are briefly summarised. All results are calculated for pupils who were attending the Gymnasium in grade five in the first wave of the survey (Table 1). Continuous variables are presented with the mean and standard deviation. Categorical variables are presented dichotomised in the table.

Of all the pupils in the sample, $49.3 \%$ were enrolled in the academic track when the strict operationalisation of "academic" is utilised, while this share increases to about $65 \%$ when comprehensive schools are also considered "academic" based on the alternative definition. The data clearly indicate that only about $12 \%$ to $18 \%$ of all pupils enrolled in the Gymnasium displayed a mismatch, depending on the form of operationalisation used. The large share of these parents who had a very high level of education is also striking, as more than $50 \%$ had higher education eligibility (Abitur). This result is approximately in line with data from official statistics. In 2016, 63.4\% of parents with a child in the academic track had higher education eligibility (Statistisches Jahrbuch Deutschland 2016 2016: 81).

\footnotetext{
4 It is known that immigrants often have high aspirations for their children, which could make them prone to ignore the teacher's recommendation. Thus, migration background might be a confounding factor (Kao and Tienda 1995).
} 


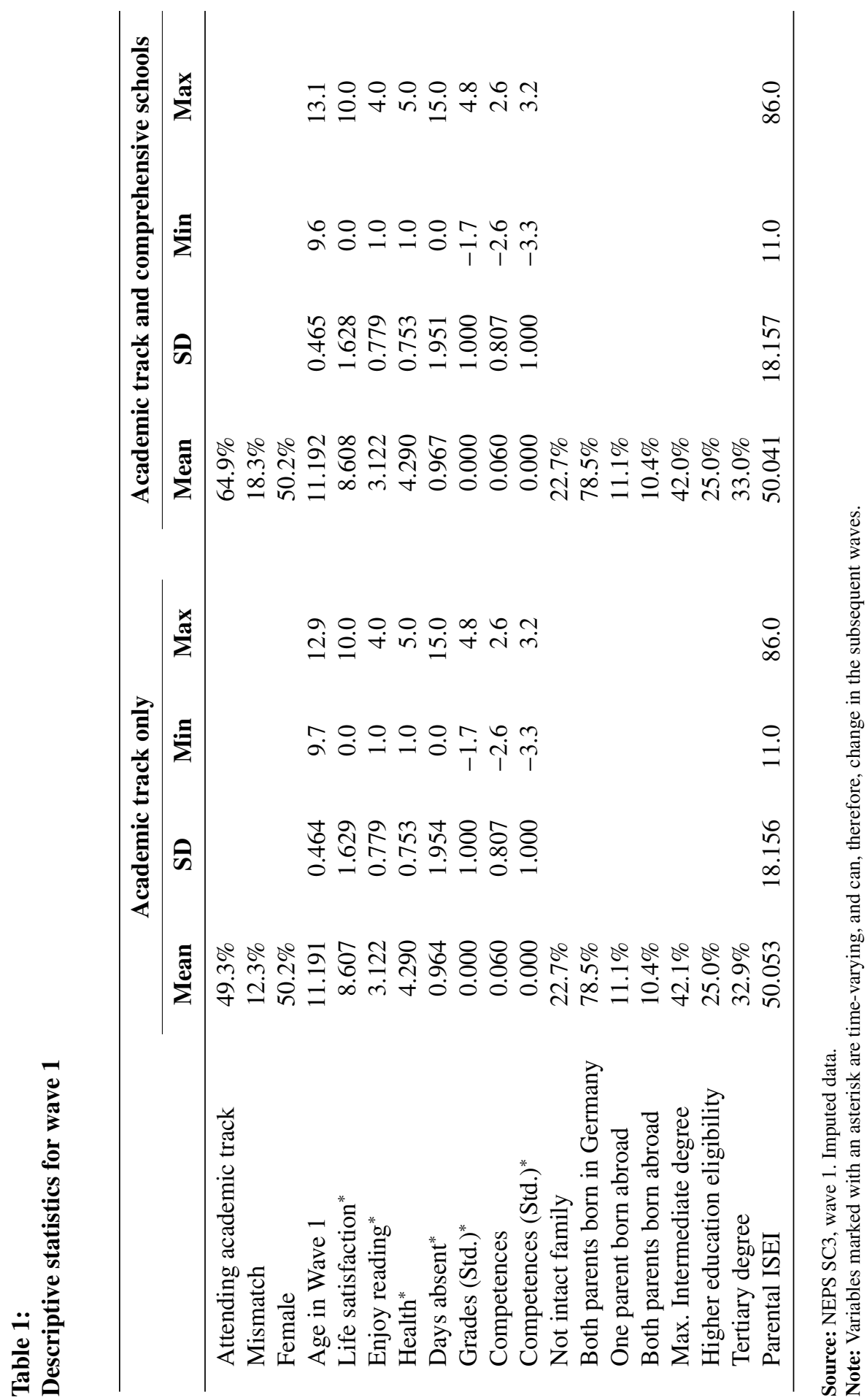




\subsection{Social origin and mismatch}

To test how social origin was associated with a mismatch, binary logistic regressions are performed (Table 2). For each operationalisation, two models are computed, one without controls and one with all control variables added. Unlike all of the following analyses, these analyses include children enrolled in the fifth grade in all types of schools who did not receive a teacher's recommendation to enrol in the academic track. Average marginal effects (AMEs) are reported. It should be noted that parental social status, measured via the ISEI level, is not included in these models, as this variable is strongly correlated with parental education, and its inclusion would undermine the effect of the education variable.

In the models without the controls added, we find a positive and statistically significant effect. For example, the results show that compared to parents with lower levels of education, parents with a university degree whose children were enrolled in the academic track (strict operationalisation) were 8.3 percentage points more likely to enrol their child in the academic track despite not having received a teacher's recommendation to do so. The results for the alternative definition of academic track that includes comprehensive school are similar. However, our conclusions change as soon as controls are added. In the strict operationalisation, a big part of the effect vanishes and the significance is lost, while the trend is still the same. When the alternative definition of the academic track that includes comprehensive schools is applied, the effect becomes smaller, but is still significant. Taken together, we conclude that the effect is reduced somewhat after the controls are added; that there is still a clear trend in both forms of operationalisation; and that highly educated parents are, on average, more prone to enrol their child in the academic track despite not having received a recommendation to do so.

\subsection{Longitudinal trajectories}

In the following analyses, mismatch status is the central explanatory variable. Multilevel growth curve models are calculated in which an interaction between the wave dummy and the mismatch variable is inserted (Rabe-Hesketh and Skrondal 2012). The educational trajectories can thus be modelled in a very flexible way, and allow for a clear graphical representation. First, we investigate whether students with a mismatch are more likely to drop out of the academic track than students who received a teacher's recommendation to enrol (retention rate). For this purpose, a binary variable that indicates whether or not a student was enrolled in the academic track in a given wave is created. By design, this share was $100 \%$ in grade five. The entire trajectories are depicted in Figure 1. Each model includes the previously introduced control variables. Complete regression tables are available in the appendix (Table A.2).

The trend is quite clear. Pupils with a mismatch tended to drop out more often than the pupils who received the recommendation. In the strict operationalisation, 


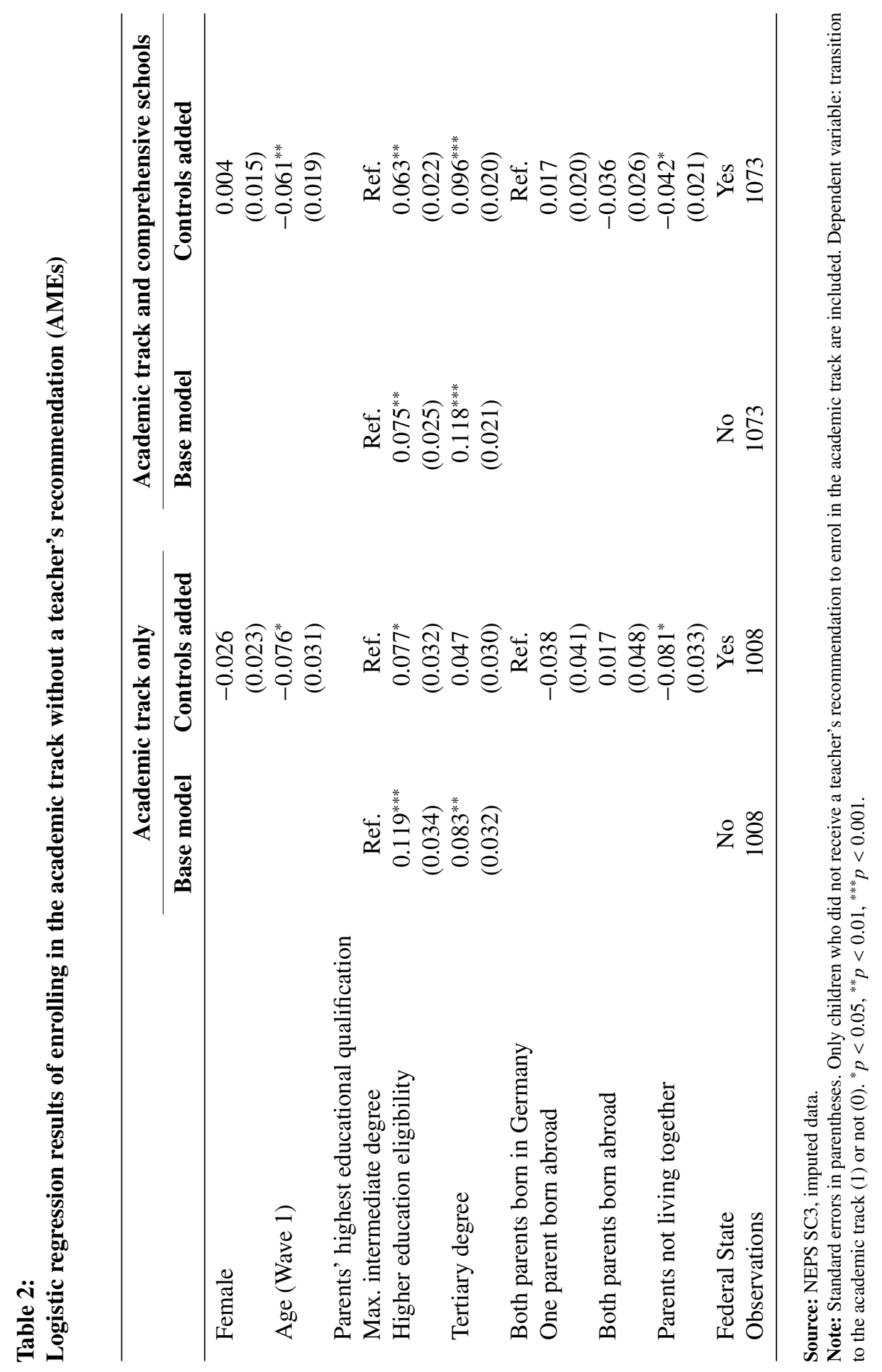


Figure 1:

Retention rates by mismatch status and form of operationalization
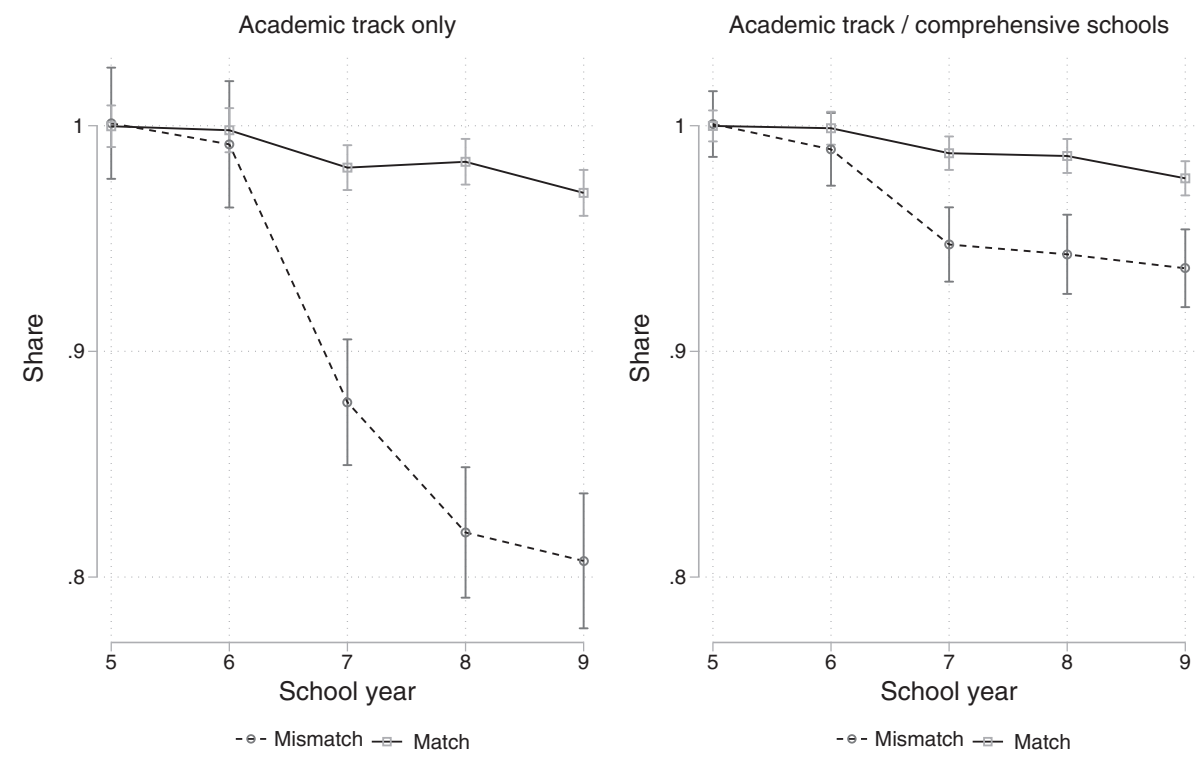

this effect is huge, and is more than 15 percentage points in wave nine. When the alternative definition of academic track that includes comprehensive schools is applied, the effect is smaller (more than five percentage points), but is still statistically significant. Additional tests for the difference between the two lines indicate that the difference is actually statistically significant on the 5\% level from grade seven onwards (not depicted). These results are in line with previous findings (Tiedemann and Billmann-Mahecha 2010).

In the next model, the trajectories of objective competences and school grades are analysed. Linear models are estimated, since the outcomes are measured continuously and are approximately normally distributed. The models include the same control variables as before to account for spurious correlations. To allow for a clearer interpretation, the model shows not the predicted outcomes, but the differences between the two groups (match/mismatch). This means that for the objective competences, a positive number represents an advantage for the pupils with a match, while for the grades, a negative number indicates an advantage for these pupils (since lower grades indicate better performance in the German system, with one being the best grade and six being the worst). This interpretation makes it convenient to test for statistical significance. As long as the zero line is not touched by the confidence bars, the difference is significant on the 5\% level. The results are 


\section{Figure 2:}

\section{Differences in competences by type of competence and form of operationalization}
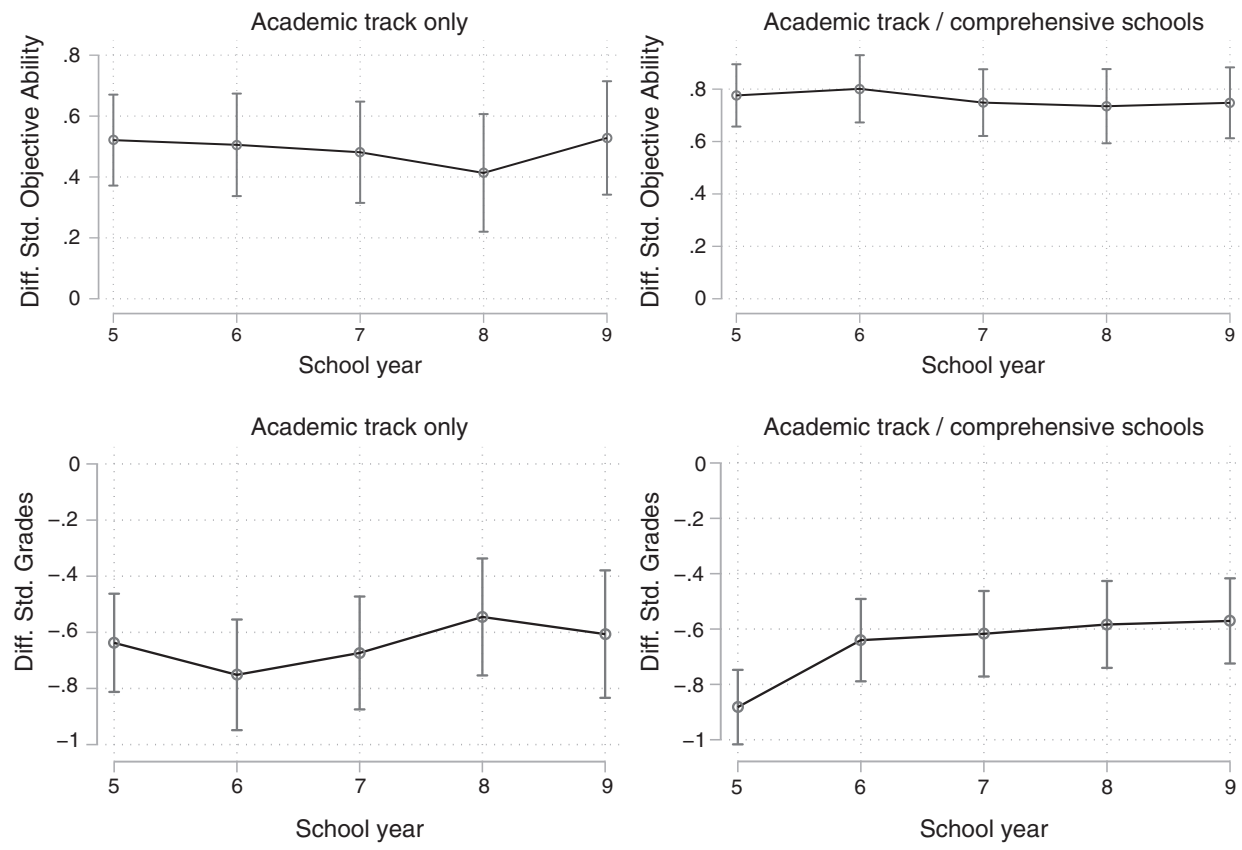

Note: The differences between the mismatch and the match status groups are depicted.

shown in Figure 2, and the complete regression tables are presented in the appendix (Table A.3).

When we look at the results for the objective competences (upper row), we can see that the differences are always positive, and that zero is never touched by the confidence bars. This means that pupils with a match status always display higher objective competences. The gap between the two groups is rather constant over time, and lies between 0.4 and 0.5 standard deviations. The difference between the two forms of operationalisation is rather small, while the effects are stronger in the alternative definition of academic track that includes comprehensive schools. The same overall conclusions can be reached for subjective grades (lower row). While the signs are reversed due to the coding scheme, the meaning is the same. The pupils with a mismatch condition always had worse outcomes; that is, numerically higher grades.

The models for the other four outcomes are built identically. The predicted outcomes are reported for both groups (Figure 3 and 4), and complete regression tables are shown in the appendix (Table A.4). Again, the results are visualised separately for both operationalisations. 
Figure 3:

Trajectories of satisfaction and enjoyment of reading by mismatch status
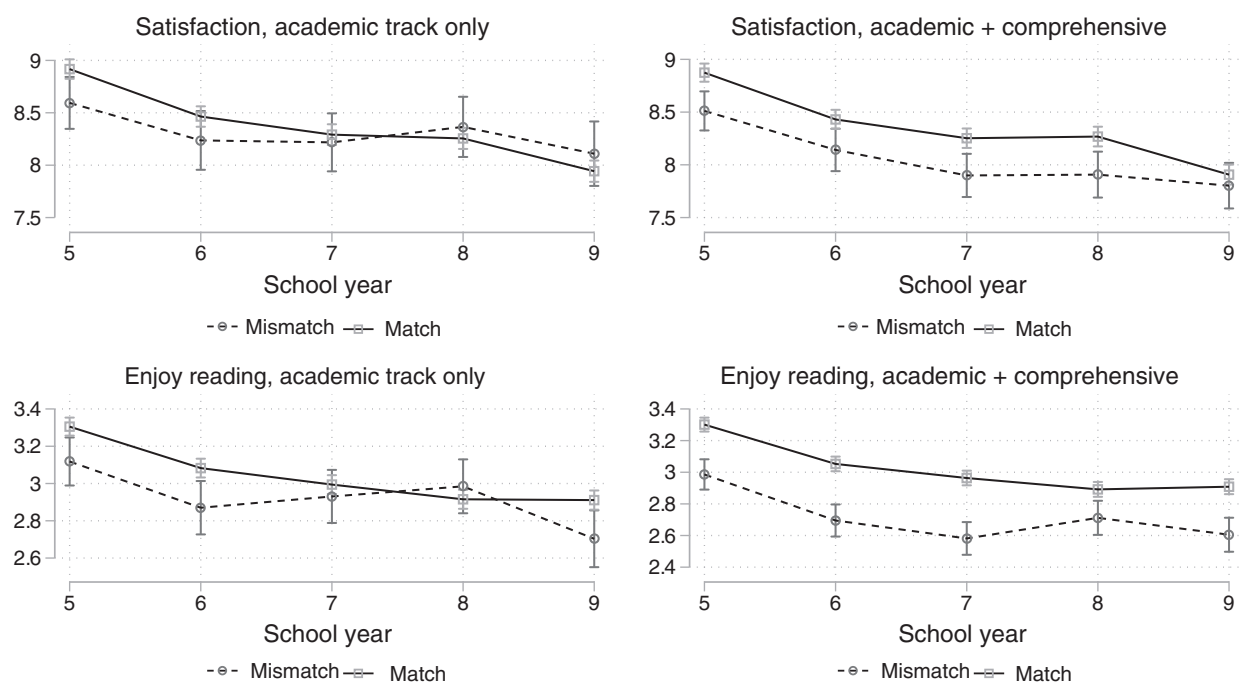

\section{Figure 4:}

Trajectories of health and days absent from school by mismatch status

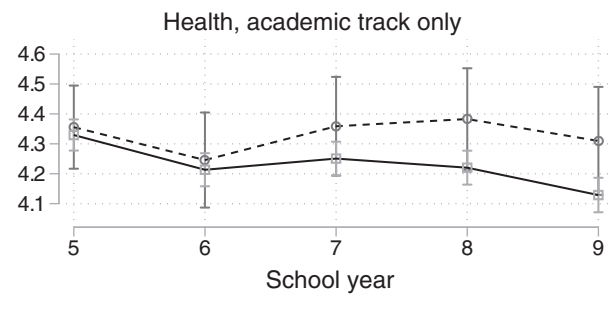

$-\ominus-$ Mismatch $-\bullet-$ Match

Days absent, academic track only

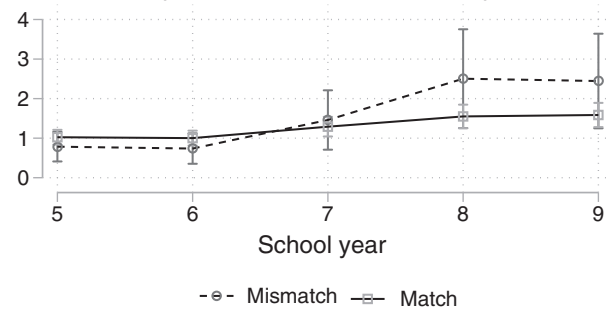

Health, academic + comprehensive

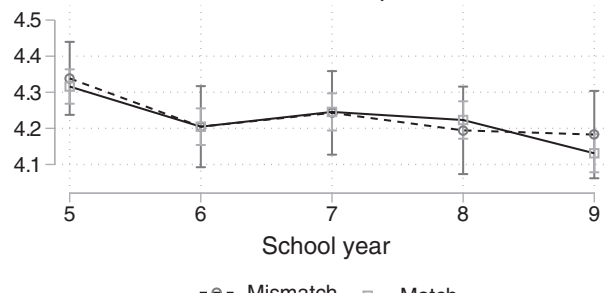

Days absent, academic + comprehensive

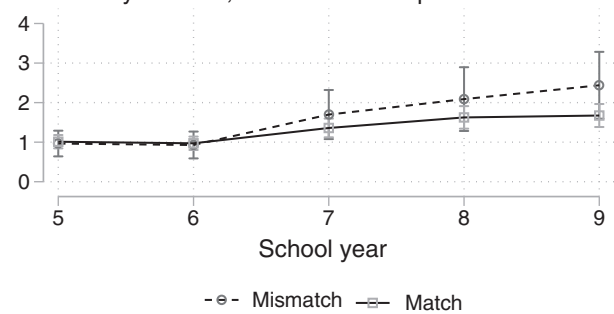


As we can see, there are virtually no differences between the matched and the mismatched pupils using the strict operationalisation. For both outcomes, satisfaction and enjoyment of reading, the confidence intervals clearly overlap. The picture is quite different when the alternative definition of the academic track that includes comprehensive schools (right side of the figure) is employed: i.e., we see clear gaps for both satisfaction and enjoyment, which indicate significant group differences. Here, we observe that pupils in the mismatch condition have lower levels of satisfaction and of enjoyment of reading.

With respect to the two final outcomes, the general health of the child and the days the child was absent from school in the last four weeks, we do not see any group differences at all, regardless of the form of operationalisation. These findings lead us to conclude that there is no association between the mismatch status and these two outcomes after controlling for various potentially confounding variables, which are the same as those used in the previous models.

\subsection{Mediation analysis}

Since the previous analyses indicate that there are significant group differences in levels of satisfaction and of enjoyment of reading, the question of whether these differences can be attributed to differences in performance, which are clearly present, arises. To investigate this question, mediation models can be applied. Again, both forms of operationalisation are used for the outcomes of satisfaction and enjoyment of reading. The models are built as follows. The first model includes the treatment (mismatch) and all controls. The second model adds both variables of performance (objective performance and grades). If the coefficients of the treatment status change, a mediation effect is present. To test this statistically, the Sobel test is applied to each model (Hayes 2018). If the coefficients are found to be statistically significant, this proves that a mediation effect is present. Results are presented in Table 3.

When interpreting the results from the strict operationalisation, we notice that the models also indicate that there is no effect of mismatch status in these findings. However, we see that the sign of the coefficient changes after the mediators are included. The mediator variables are highly significant (for satisfaction, only grades; for enjoyment, both grades and objective performance). Applying the Sobel test revealed that there is indeed a mediation effect, and that the coefficients are highly significant. However, since the baseline effect of mismatch is not significant, the total share mediated is probably very small, and these findings should, therefore, be interpreted with caution. The outcomes are clearly different when the alternative definition of academic track that includes comprehensive schools is used. Here, the mismatch variable is highly significant and negative, which suggests that there is a negative effect for pupils with a mismatch. This was also clear from the previous analyses. When the mediators are added, the coefficient of mismatch is no longer significant, which indicates that a mediation effect is present. The mediating variables are again highly significant. As the Sobel test results are highly significant 


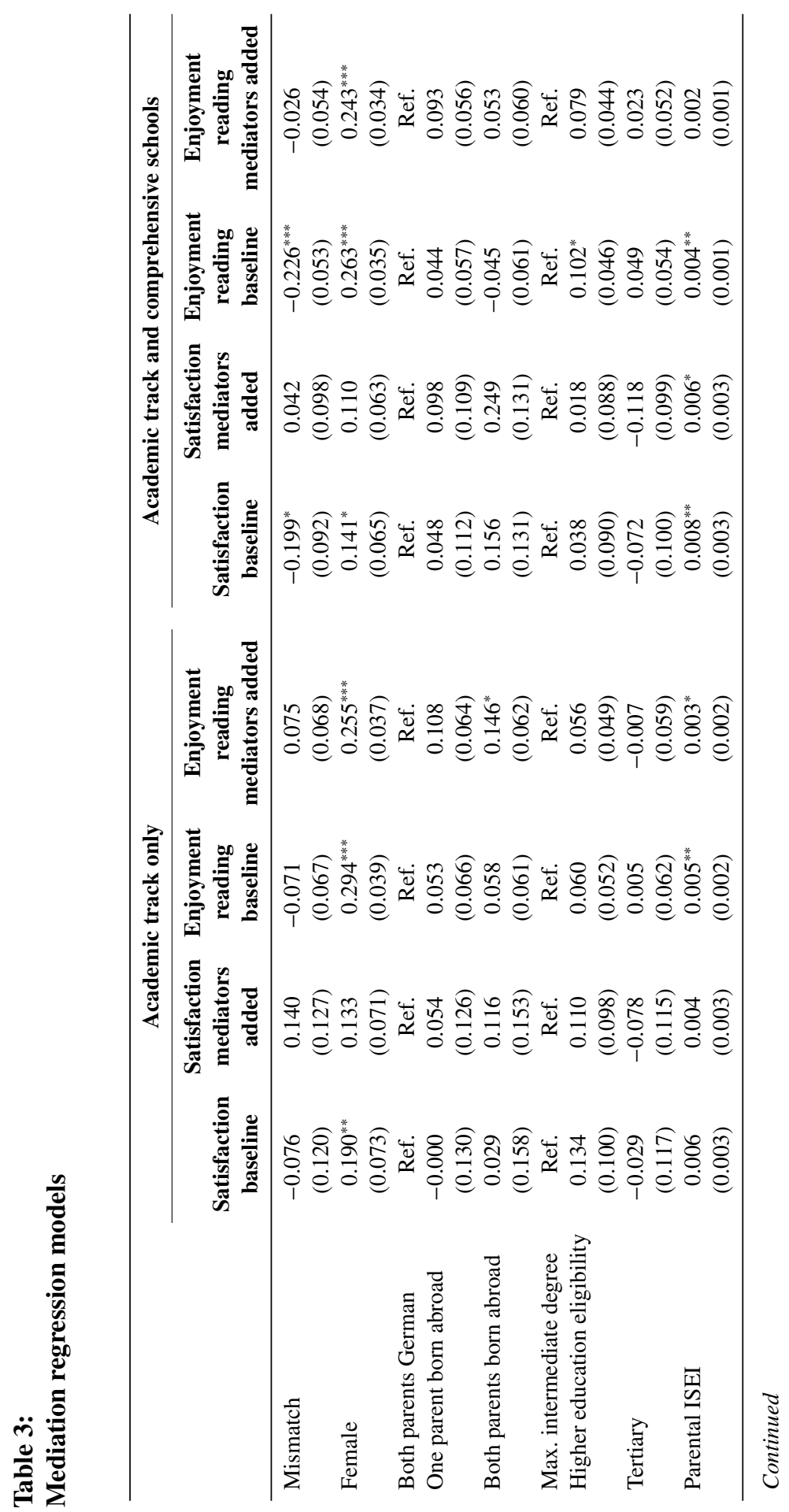




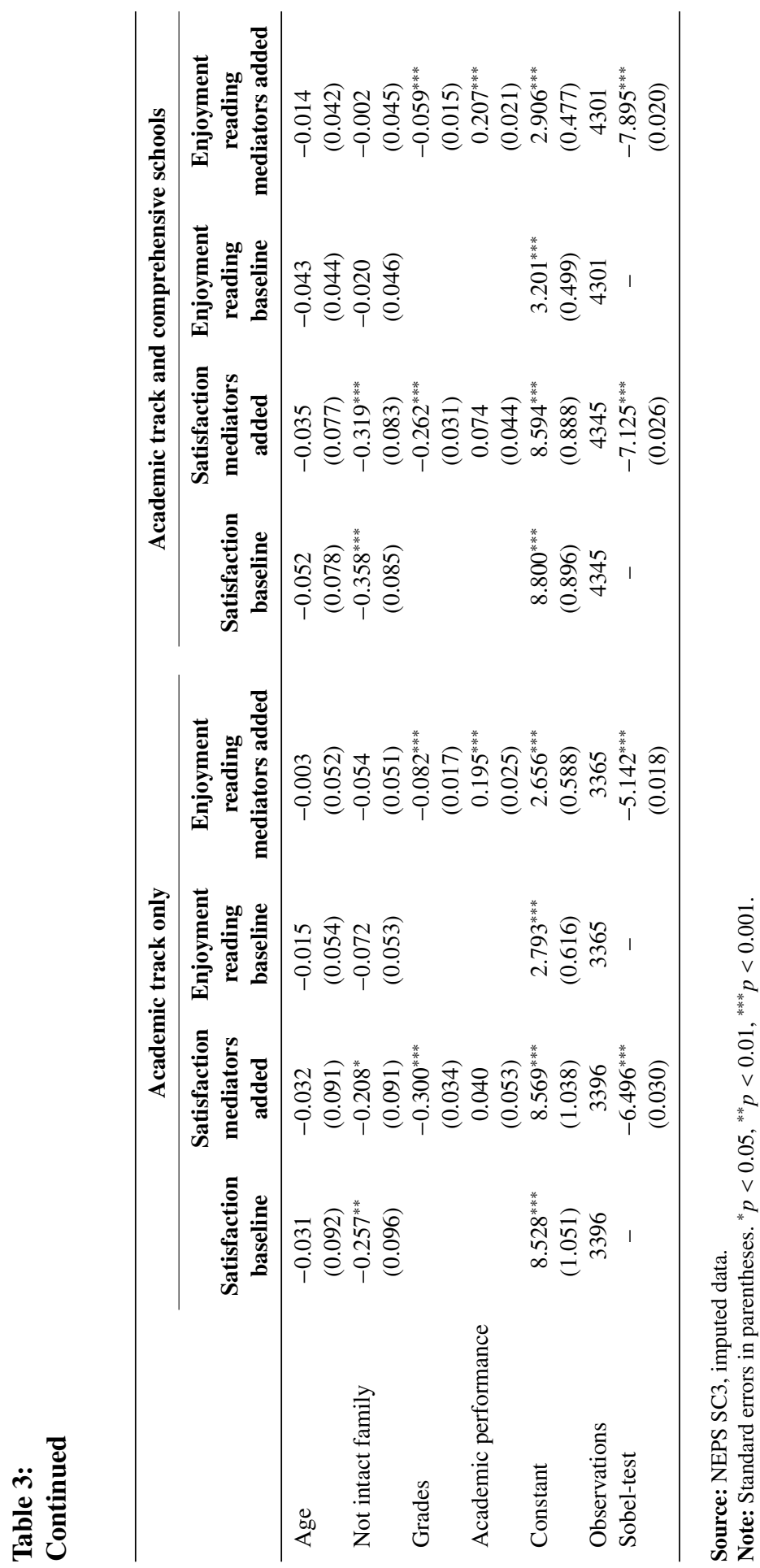


as well, we can conclude that a mediation effect is present, and that the performance differences between the two groups can explain why the pupils with a mismatch status had worse outcomes.

\section{Discussion}

We start this section by discussing the choice of the secondary education track. The models indicated that higher educated parents were more likely to deviate from a teacher's recommendation to enrol their child in a lower academic track by enrolling their child in the academic track. Since the results were stable even after controls were added, this seems to be a robust association. Even though one coefficient was no longer statistically significant, the trends remained clear. Therefore, hypothesis one is accepted. This means that the probability that a teacher's recommendation that a child be enrolled in a lower schooling track was overruled increased with the social status of the parents. The kind of operationalisation was shown to play a minor role only. This finding is in line with previous studies that also found that there is a correlation between the social origin of a pupil's parents and the choice of school track (Ditton et al. 2005). Taken together, these outcomes further confirm that highly educated parents had a strong tendency to enrol their child in the academic track, even if the child was not well-prepared for it at the time of the transition. As was discussed above, motives of status maintenance might explain this choice. By contrast, less educated parents tended to rely more on the decisions of the teacher, as they were less informed about the school system and all of the available options. These findings show that abolishing the binding character of the recommendation after elementary school appears to affect higher educated parents in particular, as their choice is decisive, and it is their responsibility to select a track for their child.

With respect to retention rates, the results were very clear. As expected, we found that the children with a mismatch status in the academic track had a significantly higher chance of dropping out and of leaving this track. This finding held for both types of operationalisations, while the results were clearly stronger when the strict operationalisation was analysed. This makes sense, since switching from the academic track to the comprehensive school was not coded as a dropout in the alternative definition of academic track that includes comprehensive schools. In short, this result is in line with our expectations, since, on average, the pupils with a mismatch status had lower performance at the start of their secondary education (this being the reason why they did not receive a recommendation to enrol in the academic track). For the academic track, it is clear that there was a selection based on performance; thus, the fact that there were dropouts was not surprising. These findings are in line with those of previous studies (Tiedemann and Billmann-Mahecha 2010). In addition, these results underline that enrolling a child in the academic track without a teacher's recommendation obviously does not guarantee that the child will have academic success or become eligible to enter higher education, even if the child joined this track at the start of her or his 
secondary education. Parents should be aware of these findings and the implications. Having to leave a track might disturb the social networks a child has built over time. Moreover, it might feel humiliating for a child to have to drop out due to substandard performance. Therefore, parents should consider these implications when overruling the decision of the teacher.

Next, we discuss the academic performance trajectory. The results from our statistical analysis showed that the gap between the pupils with a match and a mismatch was very large, and was almost constant over the entire five-year observation period. On the one hand, this finding was expected since the performance gap was the main reason for the mismatch status. However, it was very interesting to see that the gap persisted, and that there was almost no sign of catching-up processes. Even in the more stimulating learning environment of the academic track with peers who were performing well, the initially disadvantaged pupils were not, on average, able to demonstrate significant improvements and reach the level of their peers. This finding is highly relevant, as it addresses the expectation of many parents that being in the right learning environment could improve their child's academic performance. Since the finding was stable for objective and subjective competences and for both forms of operationalisation, we believe that is a robust conclusion.

However, the trajectories of the four other outcomes that were not related to academic performance were much less clear. In terms of health, no group differences at all were found in health or in days absent from school. This was a positive finding, as it indicated that even if there was a substantial gap in terms of a child's academic performance, the general health of the child was not associated with a mismatch. For the other two outcomes, life satisfaction and enjoyment of reading, the differences were only significant when the alternative definition of academic track that includes comprehensive schools was used. It is, however, not clear why the form of the operationalisation made a difference in this case. Since the finding was not very robust, we assume that the effects were rather weak, and should be interpreted with caution. Seen from the perspective of the children, this outcome was positive, as it indicated that a mismatch did not necessarily negatively affect the well-being of a child. The expectation that having a large academic performance gap compared to their peers could have a large negative influence on the satisfaction or health of mismatched pupils was not confirmed.

With respect to the mediation analysis, we did see that the negative effects were mediated by academic competences. We should be cautious in interpreting these findings, since the effect of the treatment variable mismatch was not stable, which suggests that the total effect was small. The Sobel test indicated that a mediation effect was probably present based on the measurements of performance, and that both subjective and objective performance could be the mediator. These findings are in line with our expectations. Since performance gaps between the two groups were the main reason for the mismatch, and these gaps persisted over time, it is not very surprising that a mediation effect could be observed.

What are the implications of these findings? Did the parents who ignored a teacher's recommendation and forced their child to enrol in the academic track act 
sensibly, or were they irresponsible? The findings clearly show that the expectation that pupils who had poor performance in the lower grades would catch up with their peers over time did not materialise, and that mismatched pupils had much higher chances of dropping out. For this reason, the success of the shift towards allowing parents to enrol their child in the academic track against the teacher's recommendation is highly questionable. However, if the child is successful in pursuing the academic track and does not drop out, this will enable him or her to proceed directly to higher education. Since we found that other important outcomes like health were clearly not negatively associated with a mismatch, the decision of the parents cannot be framed as irresponsible.

Finally, the limitations of the present study should be discussed. Since only observational data were available, it was not possible to estimate pure causal effects. Even if certain disturbance factors could be ruled out by including control variables, it was impossible to control for all conceivable confounding variables. Thus, the results shown here should be understood as associations, or as an attempt to approximate causal effects. With respect to the sample selection, only federal states that allowed parents to ignore the teacher's recommendation were included in the analyses. Therefore, all conclusions are only valid for these states. However, since the majority of states have abolished the binding character of the recommendation, it seems likely that these results will become more relevant in the future as more power is given to the parents to overrule the teacher's decision regarding tracking.

An additional limitation is that the NEPS survey is not perfectly representative of the overall population in Germany due to selection dropout and refusal to participate. The consequence is that highly educated parents are somewhat overrepresented in the sample. However, in this study, our main focus was on examining how mismatched students fared, rather than on investigating who these students were. While we cannot be sure that the percentages of mismatched student will be the same in the overall population, their trajectories can still be described. If we further assume that mismatched pupils from socially advantaged families will do better on average than mismatched pupils from disadvantaged families, we can conclude that the outcomes might be even worse (that is, for example, levels of satisfaction or performance could be even lower) in the general population, since they probably receive less support. Given that highly educated parents are overrepresented in the NEPS data, our estimation of the academic competences and well-being of mismatched students may even be biased downward. Finally, it should be emphasised that the study could not and should not evaluate the usefulness of the (non-) binding character of track recommendations. However, as the results presented here are similar to previous findings, we would argue that, all in all, our results are quite robust and trustworthy. 


\section{Conclusion}

Based on the German NEPS student cohort, the analyses showed that students who enrolled in the academic track after the fourth grade without a teacher's recommendation had significantly lower performance levels, and that their performance disadvantage persisted over time. Therefore, the expectation of many parents that the academic performance of a student who performed poorly in the early grades would converge with the class average over time did not seem to be justified. These outcomes could be explained by the pupils' inadequate performance, which was responsible for their negative educational trajectories. However, since the findings also showed that other outcomes like satisfaction were probably not associated with a mismatch, it appears likely that no great damage was done to the mismatched children.

Overall, the findings reported in this study can serve as a foundation for parents who face the decision of whether to enrol their child in the academic track of secondary education, even if the child did not receive a teacher's recommendation to do so. While attending the Gymnasium is the most direct route to earning the Abitur, it is important to keep in mind that there may be negative effects if the fit between a child's abilities or interests and the type of track she or he is enrolled in diverge strongly. Accordingly, it seems sensible to consider alternative pathways, which are now numerous. From a research perspective, the question of how the differences between the groups of students who did and did not have a mismatch evolve even further into the future - that is, after they leave school and enter the labour market or tertiary education - appears highly relevant. Do the children with a mismatch experience long-time negative effects, or will the trajectories of the two groups converge over time? Furthermore, even if the children with a mismatch have worse outcomes that their peers in the academic track with a match, what are the effects when they are compared to their peers who chose a less demanding educational track based on a teacher's recommendation? Investigating these highly interesting research questions could be very rewarding for future analyses. In addition, replication studies, especially from different countries and other contexts, are very welcome.

\section{References}

Allison, P. D. 2001. Missing data. Vol. 136. Thousand Oaks: Sage publications.

Billmann-Mahecha, E. and J. Tiedemann 2006. Übergangsempfehlung als kritisches Lebensereignis. Migration, Übergangsempfehlung und Fähigkeitsselbstkonzept. In Risikofaktoren kindlicher Entwicklung, ed A. Schründer-Lenzen, 193-207. Wiesbaden: Springer. https://doi.org/10.1007/978-3-531-90075-9_10

Blossfeld, H.-P., H.-G. Roßbach and J. von Maurice 2011. Education as a lifelong process. The German National Educational Panel Study (NEPS). Wiesbaden: VS Verlag für Sozialwissenschaften. 
Boudon, R. 1974. Educational growth and economic equality. Quality and Quantity 8: 1-10. https://doi.org/10.1007/BF00205861

Breen, R. and J. H. Goldthorpe 1997. Explaining educational differentials. Towards a formal rational action theory. Rationality and Society 9(3): 275-305. https://doi.org/10.1177/ 104346397009003002

Ditton, H. and J. Krüsken 2006. Der Übergang von der Grundschule in die Sekundarstufe I. Zeitschrift für Erziehungswissenschaft 9: 348-372. https://doi.org/10.1007/s11618-0060055-7

Ditton, H., J. Krüsken and M. Schauenberg 2005. Bildungsungleichheit - der Beitrag von Familie und Schule. Zeitschrift für Erziehungswissenschaft 8: 285-304. https://doi.org/10. 1007/s11618-005-0138-x

Duchhardt, C. and A. Gerdes 2012. NEPS technical report for mathematics. Scaling results of starting cohort 3 in fifth grade. NEPS Working Paper No. 19. Bamberg: Otto-FriedrichUniversität, Nationales Bildungspanel.

Dumont, H., K. Maaz, M. Neumann and M. Becker 2014. Soziale Ungleichheiten beim Übergang von der Grundschule in die Sekundarstufe I. Theorie, Forschungsstand, Interventions- und Fördermöglichkeiten. Zeitschrift für Erziehungswissenschaft 17: 141165. https://doi.org/10.1007/s11618-013-0466-1

Eckhardt, T. 2017. The Education System in the Federal Republic of Germany 2015/2016. A description of the responsibilities, structures and developments in education policy for the exchange of information in Europe. Berlin: Secretariat of the Standing Conference of the Ministers of Education and Cultural Affairs of the Länder in the Federal Republic of Germany. https://www.kmk.org/fileadmin/Dateien/pdf/Eurydice/Bildungswesen-englpdfs/dossier_en_ebook.pdf, accessed on 14 January 2021.

Esser, H. 1999. Die Konstruktion der Gesellschaft. Vol. 2. Frankfurt am Main: CampusVerlag.

Fuß, D., T. Gnambs, K. Lockl and M. Attig 2019. Competence data in NEPS. Overview of measures and variable naming conventions (starting cohorts 1 to 6). NEPS Research Data Paper. Bamberg: Leibniz Institute for Educational Trajectories.

Füssel, H.-P. et al. 2010. Der institutionelle Kontext von Übergangsentscheidungen. Rechtliche Regelungen und die Schulformwahl am Ende der Grundschulzeit. In Der Übergang von der Grundschule in die weiterführende Schule. Leistungsgerechtigkeit und regionale, soziale und ethnisch-kulturelle Disparitäten, eds K. Maaz et al., 87-106. Bonn: Bundesministerium für Bildung und Forschung.

Gresch, C., J. Baumert and K. Maaz 2010. Empfehlungsstatus, Übergangsempfehlung und der Wechsel in die Sekundarstufe I. Bildungsentscheidungen und soziale Ungleichheit. In Bildungsentscheidungen, eds J. Baumert, K. Maaz and U. Trautwein, 230-256. Wiesbaden: Springer. https://doi.org/10.1007/978-3-531-92216-4_10

Harazd, B. 2008. Was kennzeichnet Eltern, die die Grundschulempfehlung nicht wahrnehmen? In Chancenungleichheit in der Grundschule. Ursachen und Wege aus der Krise, eds J. Ramseger and M. Wagener, 95-98. Wiesbaden: Springer. https:// doi.org/10.1007/978-3-531-91108-3_12

Harazd, B. and S. van Ophuysen 2008. Was bedingt die Wahl eines nicht empfohlenen höheren Bildungsgangs? Zeitschrift für Erziehungswissenschaft 11: 626-647. https://doi. org/10.1007/s11618-008-0037-z 
Haunberger, S. and M. Teubner 2008. Bildungswünsche von Eltern und Kindern im Vergleich. In Kinderleben. Individuelle Entwicklungen in sozialen Kontexten, ed C. Alt, 293-316. Wiesbaden: Springer. https://doi.org/10.1007/978-3-531-91982-9_12

Hayes, A. F. 2018. Introduction to mediation, moderation, and conditional process analysis. A regression-based approach. Second edition. New York: Guilford Press.

Herzberg, P. Y. 2013. Determinanten subjektiven Wohlbefindens bei Jugendlichen. In Systemwechsel zwischen Projekt und Prozeß. Analysen zu den Umbrüchen in Ostdeutschland. Vol. 13, eds H. Bertram, W. Kreher and I. Müller-Hartmann, 209-246. Wiesbaden: VS Verlag für Sozialwissenschaften. https://doi.org/10.1007/978-3-663-11590-8_7

Jonkmann, K., K. Maaz, M. Neumann and C. Gresch 2010. Übergangsquoten und Zusammenhänge zu familiärem Hintergrund und schulischen Leistungen. Deskriptive Befunde. In Der Übergang von der Grundschule in die weiterführende Schule. Leistungsgerechtigkeit und regionale, soziale und ethnisch-kulturelle Disparitäten, eds. K. Maaz et al., 123-150. Bonn: Bundesministerium für Bildung und Forschung.

Kao, G. and M. Tienda 1995. Optimism and achievement. The educational performance of immigrant youth. Social Science Quarterly 76(1): 1-19.

Klein, D. 2014. MIMRGNS: Stata module to run margins after mi estimate. Statistical Software Components S457795, Boston College Department of Economics.

Klicpera, C., A. Schabmann and B. Gasteiger-Klicpera 1993. Lesen- und Schreibenlernen während der Pflichtschulzeit. Eine Längsschnittuntersuchung über die Häufigkeit und Stabilität von Lese- und Rechtschreibschwierigkeiten in einem Wiener Schulbezirk. Zeitschrift für Kinder- und Jugendpsychiatrie 21: 214-225.

Köller, O. 2004. Konsequenzen von Leistungsgruppierungen. Münster: Waxmann.

Lohmann, H. and O. Groh-Samberg 2010. Akzeptanz von Grundschulempfehlungen und Auswirkungen auf den weiteren Bildungsverlauf/Acceptance of secondary school track recommendations and their effects on educational achievement. Zeitschrift für Soziologie 39(6): 470-492. https://doi.org/10.1515/zfsoz-2010-0603

Maaz, K. et al. 2008. Der Übergang von der Grundschule in die weiterführende Schule. Die Rolle von Schüler- und Klassenmerkmalen beim Einschätzen der individuellen Lernkompetenz durch die Lehrkräfte. Schweizerische Zeitschrift für Bildungswissenschaften 30(3): 519-548. https://doi.org/10.1007/978-3-531-92216-4_7

Möller, J. and E.-M. Bonerad 2007. Fragebogen zur habituellen Lesemotivation. Psychologie in Erziehung und Unterricht 54(4): 259-267.

Möller, J. and U. Trautwein 2015. Selbstkonzept. In Pädagogische Psychologie, eds E. Wild and J. Möller, 177-199. Berlin, Heidelberg: Springer Berlin Heidelberg. https://doi.org/ 10.1007/978-3-642-41291-2_8

Neugebauer, M. 2010. Bildungsungleichheit und Grundschulempfehlung beim Übergang auf das Gymnasium. Eine Dekomposition primärer und sekundärer Herkunftseffekte/ Educational inequality and teacher recommendations at the transition to upper secondary school. A decomposition of primary and secondary effects of social origin. Zeitschrift für Soziologie 39(3): 202-214. https://doi.org/10.1515/zfsoz-2010-0303

Pearl, J. 2009. Causality. Cambridge: Cambridge University Press. https://doi.org/10.1017/ CBO9780511803161 
Pfost, M. et al. 2018. Zur Entwicklung von Gymnasiastinnen und Gymnasiasten ohne Gymnasialempfehlung. Zeitschrift für Erziehungswissenschaft 21(3): 511-534. https://doi.org/10.1007/s11618-017-0787-6

Pohl, S. et al. 2012. NEPS technical report for reading. Scaling results of starting cohort 3 in fifth grade. NEPS Working Paper No. 15, Bamberg: Otto-Friedrich-Universität, Nationales Bildungspanel.

Rabe-Hesketh, S. and A. Skrondal 2012. Multilevel and longitudinal modeling using Stata. Third edition. College Station, Texas: Stata Press Publication.

Rathmann, K., M. Herke and M. Richter 2017. Die Entwicklung der selbstberichteten Gesundheit und des Wohlbefindens in der Sekundarstufe. Eine Analyse individueller Wachstumskurven. Das Gesundheitswesen 79(8/9): 656-804. https://doi.org/10.1055/s0037-1606032

Ravens-Sieberer, U., E. Görtler and M. Bullinger 2000. Subjektive Gesundheit und Gesundheitsverhalten von Kindern und Jugendlichen. Eine Befragung Hamburger Schüler im Rahmen der schulärztlichen Untersuchung. Das Gesundheitswesen 62(3): 148-155. https://doi.org/10.1055/s-2000-10487

Schulze, A., F. Wolter and R. Unger 2009. Bildungschancen von Grundschülern. Die Bedeutung des Klassen- und Schulkontextes am Übergang auf die Sekundarstufe I. Kölner Zeitschrift für Soziologie und Sozialpsychologie 61(3): 411-435. https://doi.org/10.1007/ s11577-009-0072-7

Sewell, W. H. and V. P. Shah 1968. Social class, parental encouragement, and educational aspirations. American Journal of Sociology 73(5): 559-572. https://doi.org/10.1086/ 224530

Statistisches Bundesamt 2016. Statistisches Jahrbuch Deutschland 2016. Wiesbaden: Statistisches Bundesamt.

Stern, E. 2008. Verpasste Chancen? Was wir aus der LOGIK-Studie über den Mathematikunterricht lernen können. In Entwicklung von der Kindheit bis zum Erwachsenenalter. Befunde der Münchner Längsschnittstudie LOGIK, ed. W. Schneider, 187-202. Weinheim: Beltz.

Stocké, V. 2007. Explaining Educational Decision and Effects of Families' Social Class Position. An Empirical Test of the Breen Goldthorpe Model of Educational Attainment. European Sociological Review 23(4): 505-519. https://doi.org/10.1093/esr/jcm014

Stubbe, T. C. and W. Bos 2008. Schullaufbahnempfehlungen von Lehrkräften und Schullaufbahnentscheidungen von Eltern am Ende der vierten Jahrgangsstufe. Empirische Pädagogik 22(1): 49-63.

Tiedemann, J. and E. Billmann-Mahecha 2010. Wie erfolgreich sind Gymnasiasten ohne Gymnasialempfehlung? Die Kluft zwischen Schullaufbahnempfehlung und Schulformwahl der Eltern. Zeitschrift für Erziehungswissenschaft 13(4): 649-660. https:// doi.org/10.1007/s11618-010-0146-3

TNS Infratest Sozialforschung 2009. Leben in Deutschland. Befragung 2009 zur sozialen Lage der Haushalte. Personenfragebogen für alle. In SOEP 2009 - Erhebungsinstrumente 2009 (Welle 26) des Sozio-oekonomischen Panels. SOEP Survey Papers 106: Series A. Berlin: DIW/SOEP. 
Triventi, M. 2013. The role of higher education stratification in the reproduction of social inequality in the labor market. Research in Social Stratification and Mobility 32(1): 45-63. https://doi.org/10.1016/j.rssm.2013.01.003

von Collani, G. and P. Y. Herzberg 2003. Eine revidierte Fassung der deutschsprachigen Skala zum Selbstwertgefühl von Rosenberg. Zeitschrift für Differentielle und Diagnostische Psychologie 24: 3-7. https://doi.org/10.1024//0170-1789.24.1.3

Zeinz, H. and O. Köller 2006. Noten, soziale Vergleiche und Selbstkonzepte in der Grundschule. In Risikofaktoren kindlicher Entwicklung, ed. A. Schründer-Lenzen, 177190. Wiesbaden: VS Verlag für Sozialwissenschaften. https://doi.org/10.1007/978-3-53190075-9_9

\section{Appendix}

Table A.1:

Imputed data summary

\begin{tabular}{lccccc}
\hline & \multicolumn{2}{c}{ Academic track only } & & \multicolumn{2}{c}{ Academic track and comprehensive } \\
\cline { 2 - 3 } \cline { 5 - 6 } Variable & Complete & Imputed & & Complete & Imputed \\
\hline Competences & 7244 & 197 & & 7244 & 188 \\
Enjoy reading & 7870 & 175 & & 7883 & 162 \\
Satisfaction & 8071 & 103 & & 8084 & 90 \\
Parental ISEI & 8092 & 43 & & 8092 & 43 \\
Age Wave 1 & 7658 & 220 & & 7658 & 219 \\
Grade Math & 7691 & 163 & & 7703 & 150 \\
Grade German & 7700 & 165 & & 7711 & 152 \\
Health & 8020 & 78 & & 8033 & 65 \\
Parental Education & 8212 & 2 & & 8212 & 2 \\
Migration & 7852 & 120 & & 7852 & 120 \\
Days absent & 6686 & 220 & & 6699 & 207 \\
\hline
\end{tabular}

Note: Variables that are not included in this list were not imputed since either no values are missing or cases with missing information were deleted. Some central variables were not imputed, but all cases with missing information were dropped since the information is too critical to be imputed (e.g., type of track attended). 

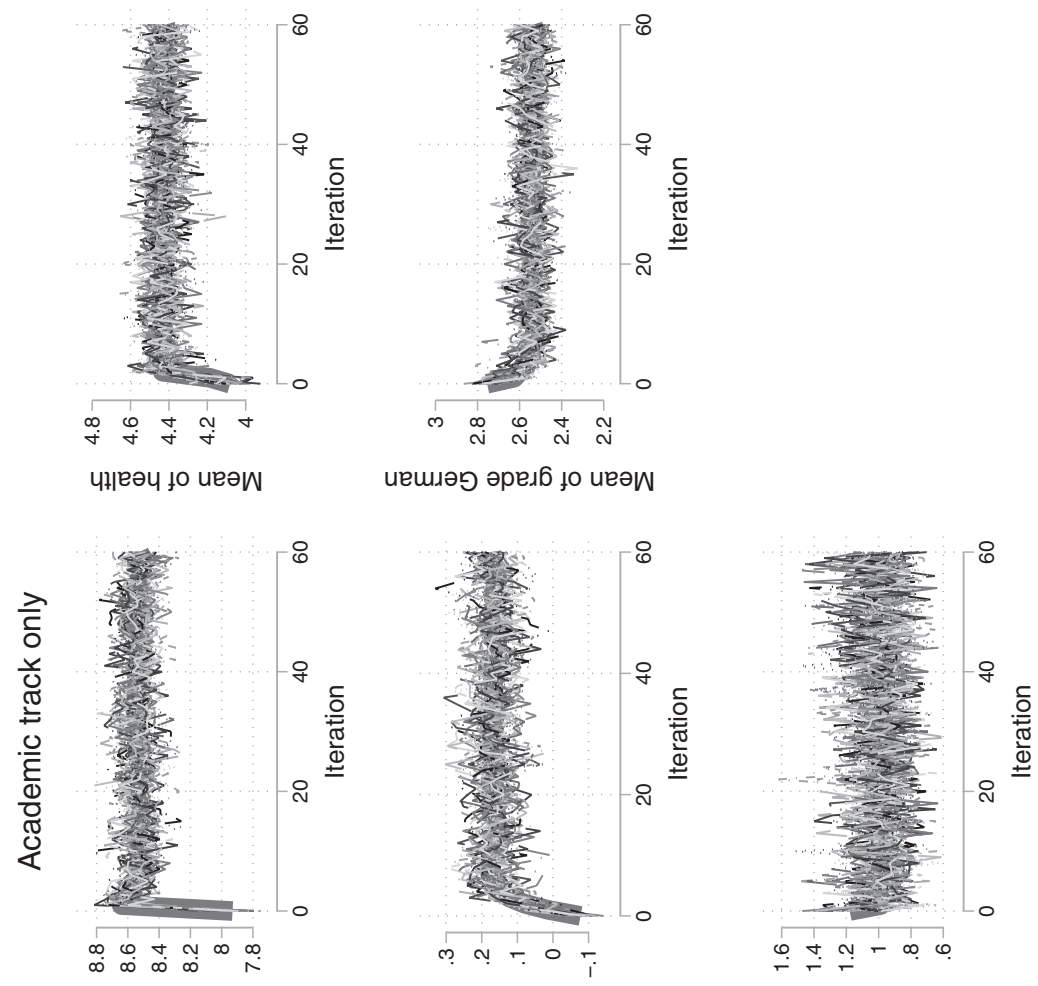

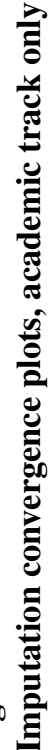

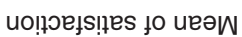

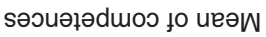

Łuәsqe sкер до иеәW
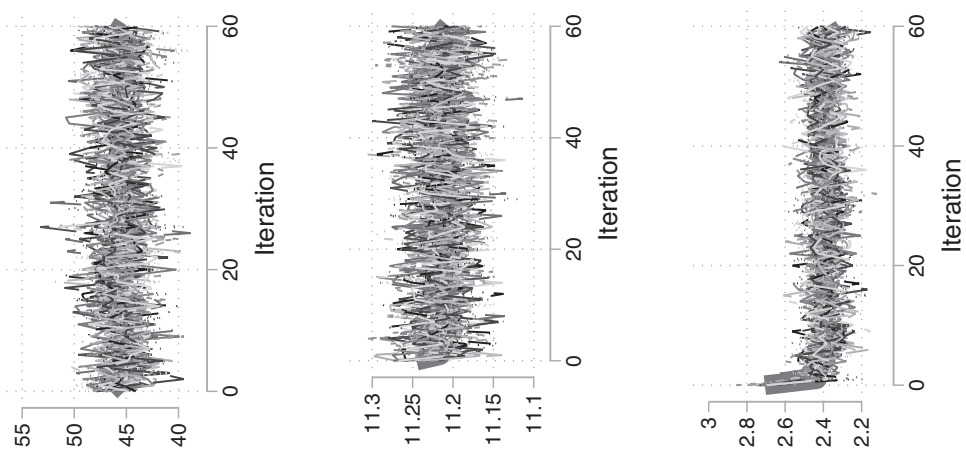

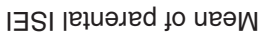

ә6е ๖о иеәพ

บıеW әрел6 јо иеәW 

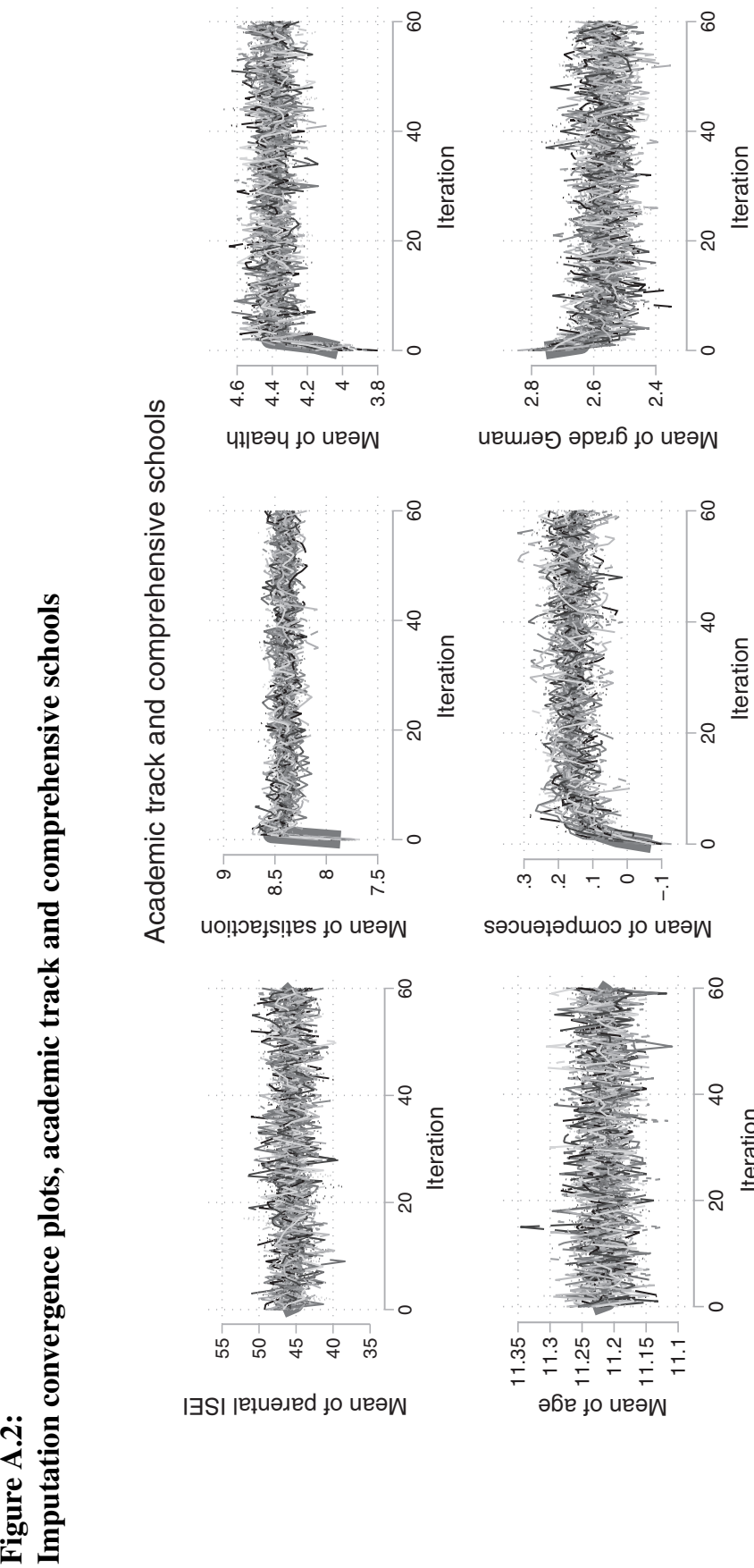

иещләэ әрел6 јо иеәพ

पा

\section{.}

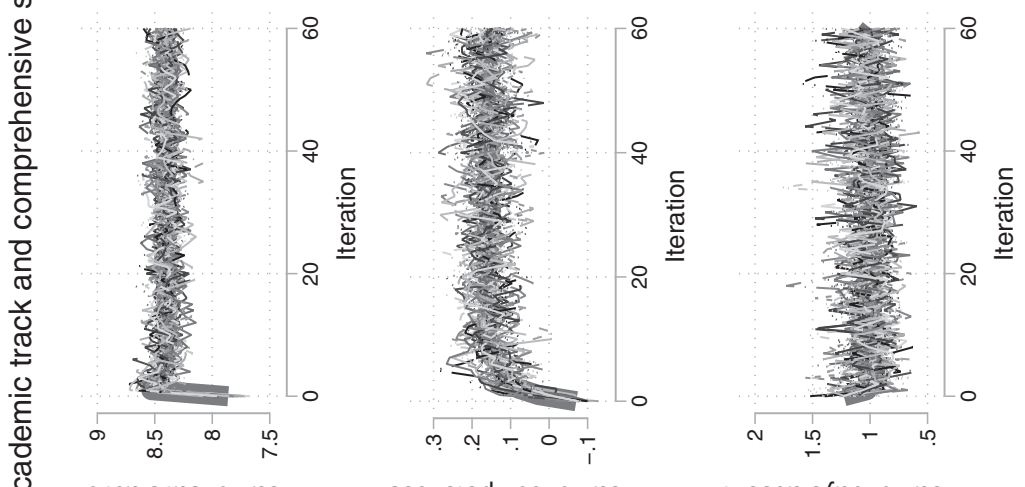

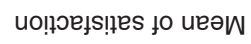

sәวนәเәdmoว ๖о иеәพ

ıuәsqe skep fo ueəw
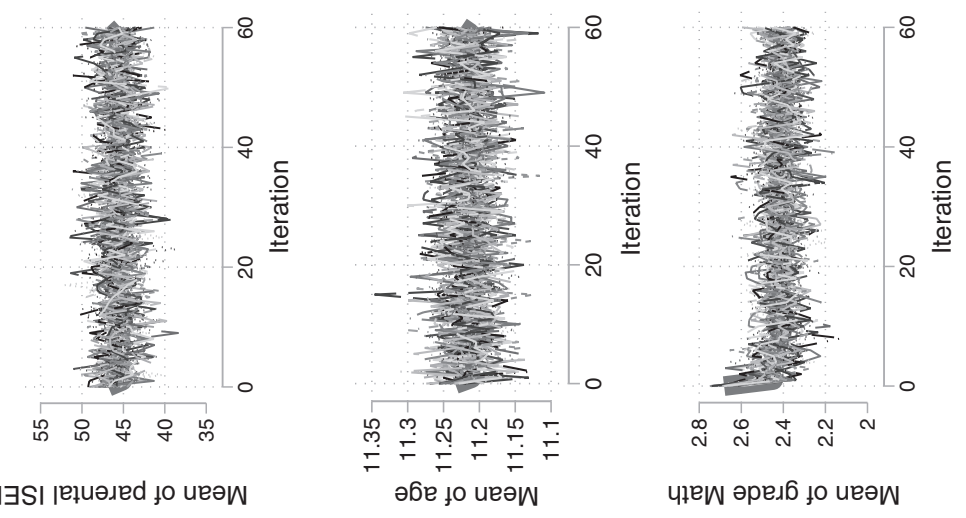

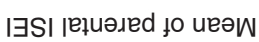

әбе јо иеә'

ч1еพ әрел6 „о иеәW 
Table A.2:

Numerical regression output for retention rates

\begin{tabular}{|c|c|c|c|c|}
\hline & \multicolumn{2}{|c|}{$\begin{array}{l}\text { Academic } \\
\text { track only }\end{array}$} & \multicolumn{2}{|c|}{$\begin{array}{l}\text { Academic track } \\
\text { and comprehensive }\end{array}$} \\
\hline & $\begin{array}{l}\text { Base } \\
\text { model }\end{array}$ & $\begin{array}{c}\text { Controls } \\
\text { added }\end{array}$ & $\begin{array}{l}\text { Base } \\
\text { model }\end{array}$ & $\begin{array}{c}\text { Controls } \\
\text { added }\end{array}$ \\
\hline Recommendation & $\begin{array}{c}-0.001 \\
(0.014)\end{array}$ & $\begin{array}{c}-0.000 \\
(0.014)\end{array}$ & $\begin{array}{c}-0.001 \\
(0.008)\end{array}$ & $\begin{array}{c}0.000 \\
(0.008)\end{array}$ \\
\hline Wave 2 & $\begin{array}{c}-0.009 \\
(0.016)\end{array}$ & $\begin{array}{c}-0.009 \\
(0.016)\end{array}$ & $\begin{array}{c}-0.011 \\
(0.010)\end{array}$ & $\begin{array}{c}-0.011 \\
(0.010)\end{array}$ \\
\hline Wave 3 & $\begin{array}{l}-0.124^{* * *} \\
(0.016)\end{array}$ & $\begin{array}{l}-0.124^{* * *} \\
(0.016)\end{array}$ & $\begin{array}{l}-0.053^{* * *} \\
(0.010)\end{array}$ & $\begin{array}{l}-0.053^{* * *} \\
(0.010)\end{array}$ \\
\hline Wave 4 & $\begin{array}{l}-0.181^{* * *} \\
(0.017)\end{array}$ & $\begin{array}{l}-0.181^{* * *} \\
(0.017)\end{array}$ & $\begin{array}{l}-0.057^{* * *} \\
(0.010)\end{array}$ & $\begin{array}{l}-0.058^{* * *} \\
(0.010)\end{array}$ \\
\hline Wave 5 & $\begin{array}{l}-0.195^{* * *} \\
(0.017)\end{array}$ & $\begin{array}{l}-0.194^{* * *} \\
(0.017)\end{array}$ & $\begin{array}{c}-0.064^{* * *} \\
(0.010)\end{array}$ & $\begin{array}{l}-0.064^{* * *} \\
(0.010)\end{array}$ \\
\hline Recommendation $*$ Wave 2 & $\begin{array}{c}0.008 \\
(0.017)\end{array}$ & $\begin{array}{c}0.008 \\
(0.017)\end{array}$ & $\begin{array}{c}0.010 \\
(0.010)\end{array}$ & $\begin{array}{c}0.010 \\
(0.010)\end{array}$ \\
\hline Recommendation $*$ Wave 3 & $\begin{array}{l}0.106^{* * *} \\
(0.017)\end{array}$ & $\begin{array}{l}0.105^{* * *} \\
(0.017)\end{array}$ & $\begin{array}{l}0.041^{* * *} \\
(0.011)\end{array}$ & $\begin{array}{l}0.041^{* * *} \\
(0.011)\end{array}$ \\
\hline Recommendation $*$ Wave 4 & $\begin{array}{l}0.166^{* * *} \\
(0.018)\end{array}$ & $\begin{array}{l}0.166^{* * *} \\
(0.018)\end{array}$ & $\begin{array}{l}0.044^{* * *} \\
(0.011)\end{array}$ & $\begin{array}{l}0.044^{* * *} \\
(0.011)\end{array}$ \\
\hline Recommendation $*$ Wave 5 & $\begin{array}{l}0.165^{* * *} \\
(0.018)\end{array}$ & $\begin{array}{l}0.164^{* * *} \\
(0.018)\end{array}$ & $\begin{array}{l}0.041^{* * *} \\
(0.011)\end{array}$ & $\begin{array}{l}0.041^{* * *} \\
(0.011)\end{array}$ \\
\hline Female & & $\begin{array}{c}0.006 \\
(0.006)\end{array}$ & & $\begin{array}{c}0.006 \\
(0.004)\end{array}$ \\
\hline Both parents born in Germany & & Ref. & & Ref. \\
\hline One parent born abroad & & $\begin{array}{c}-0.017 \\
(0.010)\end{array}$ & & $\begin{array}{c}-0.001 \\
(0.007)\end{array}$ \\
\hline Both parents born abroad & & $\begin{array}{l}0.028^{*} \\
(0.012)\end{array}$ & & $\begin{array}{l}0.022^{* *} \\
(0.008)\end{array}$ \\
\hline Max. intermediate degree & & Ref. & & Ref. \\
\hline Higher education eligibility & & $\begin{array}{c}0.001 \\
(0.009)\end{array}$ & & $\begin{array}{c}-0.002 \\
(0.006)\end{array}$ \\
\hline Tertiary degree & & $\begin{array}{c}-0.006 \\
(0.010)\end{array}$ & & $\begin{array}{c}-0.007 \\
(0.007)\end{array}$ \\
\hline Parental ISEI & & $\begin{array}{c}0.000 \\
(0.000)\end{array}$ & & $\begin{array}{c}0.000 \\
(0.000)\end{array}$ \\
\hline Age (Wave 1) & & $\begin{array}{r}-0.019^{*} \\
(0.008)\end{array}$ & & $\begin{array}{c}-0.004 \\
(0.006)\end{array}$ \\
\hline Not intact family & & $\begin{array}{c}0.001 \\
(0.008)\end{array}$ & & $\begin{array}{c}-0.003 \\
(0.006)\end{array}$ \\
\hline Constant & $\begin{array}{l}1.001^{* * *} \\
(0.013)\end{array}$ & $\begin{array}{l}1.207^{* * *} \\
(0.094)\end{array}$ & $\begin{array}{l}1.000^{* * *} \\
(0.007)\end{array}$ & $\begin{array}{l}1.038^{* * *} \\
(0.066)\end{array}$ \\
\hline Observations & 3949 & 3949 & 5146 & 5146 \\
\hline
\end{tabular}

Source: NEPS SC3, imputed data.

Note: Standard errors in parentheses. ${ }^{*} p<0.05,{ }^{* *} p<0.01,{ }^{* * *} p<0.001$. 
Table A.3:

Numerical regression results for both competence measures

\begin{tabular}{|c|c|c|c|c|}
\hline & $\begin{array}{c}\text { Competences, } \\
\text { academic } \\
\text { only }\end{array}$ & $\begin{array}{c}\text { Grades, } \\
\text { academic } \\
\text { only }\end{array}$ & $\begin{array}{c}\text { Competences, } \\
\text { academic/ } \\
\text { comprehensive }\end{array}$ & $\begin{array}{c}\text { Grades, } \\
\text { academic/ } \\
\text { comprehensive }\end{array}$ \\
\hline Recommendation & $\begin{array}{l}0.521^{* * *} \\
(0.076)\end{array}$ & $\begin{array}{c}-0.637^{* * *} \\
(0.089)\end{array}$ & $\begin{array}{l}0.776^{* * *} \\
(0.061)\end{array}$ & $\begin{array}{c}-0.882^{* * *} \\
(0.069)\end{array}$ \\
\hline Wave 2 & $\begin{array}{c}-0.037 \\
(0.062)\end{array}$ & $\begin{array}{l}0.410^{* * *} \\
(0.098)\end{array}$ & $\begin{array}{r}-0.091^{*} \\
(0.041)\end{array}$ & $\begin{array}{c}-0.015 \\
(0.072)\end{array}$ \\
\hline Wave 3 & $\begin{array}{c}-0.021 \\
(0.062)\end{array}$ & $\begin{array}{c}0.307^{* *} \\
(0.099)\end{array}$ & $\begin{array}{c}-0.045 \\
(0.041)\end{array}$ & $\begin{array}{c}-0.039 \\
(0.075)\end{array}$ \\
\hline Wave 4 & $\begin{array}{c}0.007 \\
(0.079)\end{array}$ & $\begin{array}{r}0.234^{*} \\
(0.103)\end{array}$ & $\begin{array}{c}-0.070 \\
(0.052)\end{array}$ & $\begin{array}{c}-0.026 \\
(0.077)\end{array}$ \\
\hline Wave 5 & $\begin{array}{c}-0.105 \\
(0.074)\end{array}$ & $\begin{array}{c}0.336^{* *} \\
(0.114)\end{array}$ & $\begin{array}{c}-0.073 \\
(0.046)\end{array}$ & $\begin{array}{c}0.018 \\
(0.074)\end{array}$ \\
\hline Recommendation $*$ Wave 2 & $\begin{array}{c}-0.016 \\
(0.065)\end{array}$ & $\begin{array}{c}-0.114 \\
(0.103)\end{array}$ & $\begin{array}{c}0.025 \\
(0.045)\end{array}$ & $\begin{array}{c}0.242^{* *} \\
(0.079)\end{array}$ \\
\hline Recommendation $*$ Wave 3 & $\begin{array}{c}-0.040 \\
(0.064)\end{array}$ & $\begin{array}{c}-0.036 \\
(0.105)\end{array}$ & $\begin{array}{c}-0.027 \\
(0.044)\end{array}$ & $\begin{array}{c}0.265^{* *} \\
(0.081)\end{array}$ \\
\hline Recommendation $*$ Wave 4 & $\begin{array}{c}-0.108 \\
(0.082)\end{array}$ & $\begin{array}{c}0.092 \\
(0.109)\end{array}$ & $\begin{array}{c}-0.041 \\
(0.055)\end{array}$ & $\begin{array}{l}0.299^{* * *} \\
(0.083)\end{array}$ \\
\hline Recommendation $*$ Wave 5 & $\begin{array}{c}0.007 \\
(0.077)\end{array}$ & $\begin{array}{c}0.031 \\
(0.119)\end{array}$ & $\begin{array}{c}-0.028 \\
(0.050)\end{array}$ & $\begin{array}{l}0.311^{* * *} \\
(0.081)\end{array}$ \\
\hline Female & $\begin{array}{c}0.124^{* *} \\
(0.046)\end{array}$ & $\begin{array}{c}-0.171^{* * *} \\
(0.045)\end{array}$ & $\begin{array}{c}0.099^{*} \\
(0.042)\end{array}$ & $\begin{array}{c}-0.128^{* *} \\
(0.039)\end{array}$ \\
\hline Both parents born in Germany & Ref. & Ref. & Ref. & Ref. \\
\hline One parent born abroad & $\begin{array}{r}-0.186^{*} \\
(0.076)\end{array}$ & $\begin{array}{c}0.139 \\
(0.075)\end{array}$ & $\begin{array}{r}-0.177^{*} \\
(0.071)\end{array}$ & $\begin{array}{r}0.142^{*} \\
(0.065)\end{array}$ \\
\hline Both parents born abroad & $\begin{array}{c}-0.344^{* * *} \\
(0.088)\end{array}$ & $\begin{array}{l}0.318^{* * *} \\
(0.085)\end{array}$ & $\begin{array}{c}-0.404^{* * *} \\
(0.086)\end{array}$ & $\begin{array}{l}0.299^{* * *} \\
(0.072)\end{array}$ \\
\hline Max. intermediate degree & Ref. & Ref. & Ref. & Ref. \\
\hline Higher education eligibility & $\begin{array}{c}-0.007 \\
(0.066)\end{array}$ & $\begin{array}{c}-0.043 \\
(0.063)\end{array}$ & $\begin{array}{c}0.104 \\
(0.060)\end{array}$ & $\begin{array}{c}-0.011 \\
(0.054)\end{array}$ \\
\hline Tertiary degree & $\begin{array}{c}0.010 \\
(0.074)\end{array}$ & $\begin{array}{r}-0.152^{*} \\
(0.072)\end{array}$ & $\begin{array}{c}0.105 \\
(0.068)\end{array}$ & $\begin{array}{r}-0.136^{*} \\
(0.062)\end{array}$ \\
\hline Parental ISEI & $\begin{array}{c}0.006^{* *} \\
(0.002)\end{array}$ & $\begin{array}{r}-0.004^{*} \\
(0.002)\end{array}$ & $\begin{array}{l}0.007^{* * *} \\
(0.002)\end{array}$ & $\begin{array}{r}-0.003^{*} \\
(0.002)\end{array}$ \\
\hline Age (Wave 1) & $\begin{array}{c}-0.085 \\
(0.059)\end{array}$ & $\begin{array}{c}0.027 \\
(0.056)\end{array}$ & $\begin{array}{r}-0.115^{*} \\
(0.046)\end{array}$ & $\begin{array}{c}0.063 \\
(0.047)\end{array}$ \\
\hline Not intact family & $\begin{array}{c}-0.023 \\
(0.060)\end{array}$ & $\begin{array}{c}0.177^{* *} \\
(0.059)\end{array}$ & $\begin{array}{c}-0.046 \\
(0.054)\end{array}$ & $\begin{array}{c}0.145^{* *} \\
(0.050)\end{array}$ \\
\hline Federal state & Yes & Yes & Yes & Yes \\
\hline Constant & $\begin{array}{c}0.528 \\
(0.685)\end{array}$ & $\begin{array}{c}0.143 \\
(0.642)\end{array}$ & $\begin{array}{c}0.465 \\
(0.537)\end{array}$ & $\begin{array}{c}-0.086 \\
(0.550)\end{array}$ \\
\hline Observations & 3704 & 3869 & 4795 & 4978 \\
\hline
\end{tabular}

Source: NEPS SC3, imputed data.

Note: Standard errors in parentheses. ${ }^{*} p<0.05,{ }^{* *} p<0.01,{ }^{* * *} p<0.001$. 


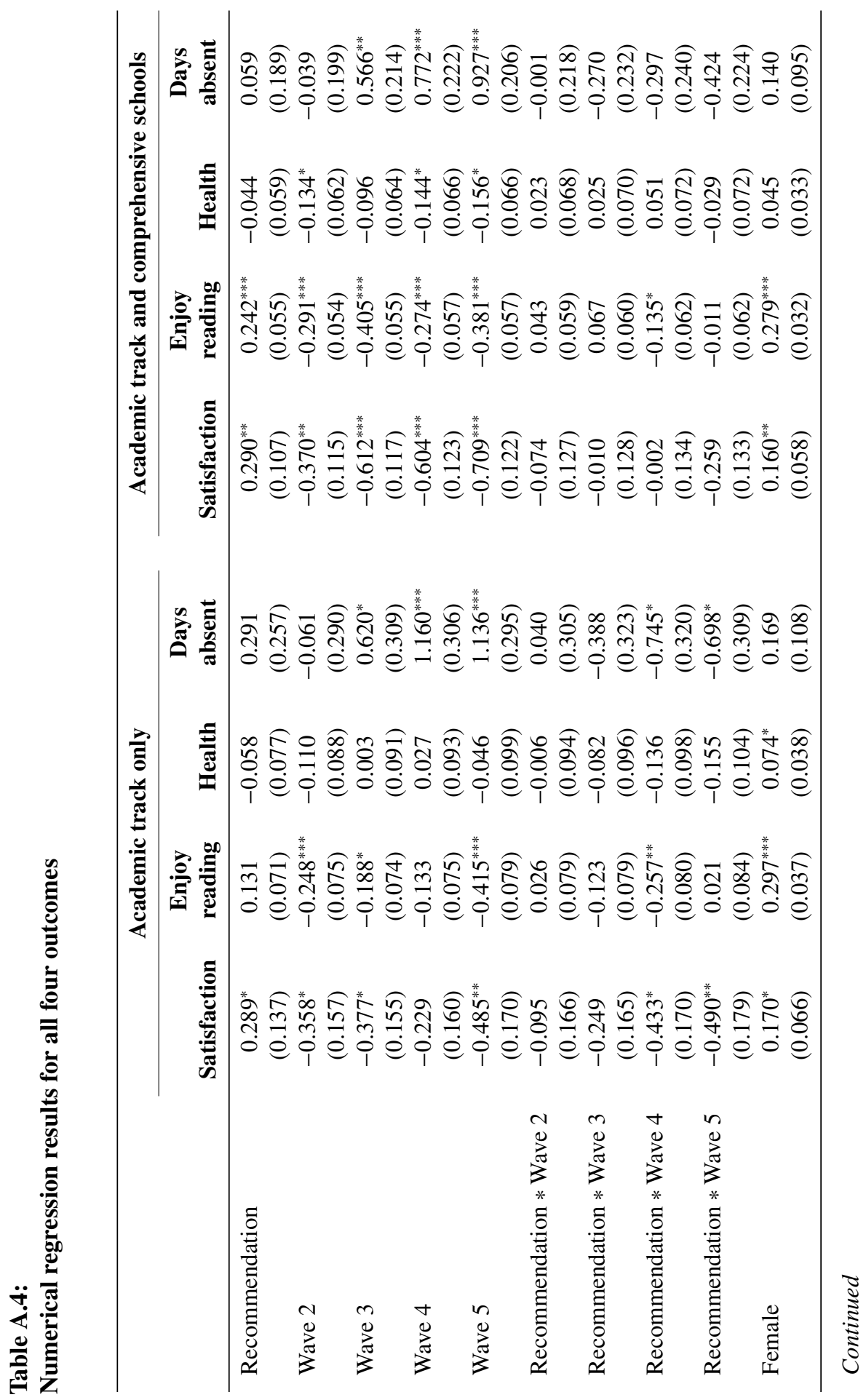




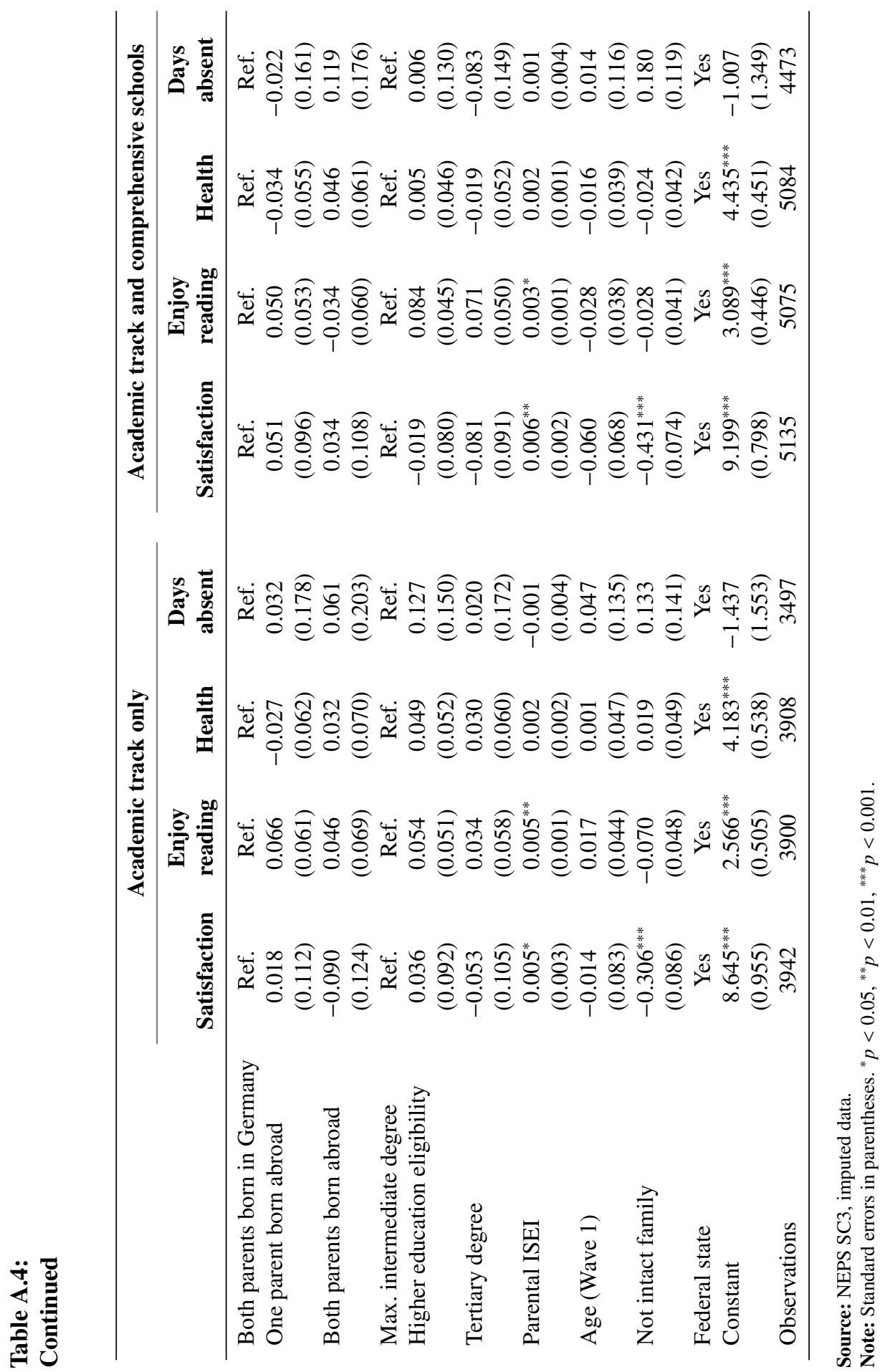


Open Access This article is published under the terms of the Creative Commons Attribution 4.0 International License (https://creativecommons.org/licenses/by/4.0/) that allows the sharing, use and adaptation in any medium, provided that the user gives appropriate credit, provides a link to the license, and indicates if changes were made. 